University of Nebraska - Lincoln

DigitalCommons@University of Nebraska - Lincoln

7-8-2008

\title{
Mitochondrial DNA evolution in the Anaxyrus boreas species group
}

Anna M. Goebel

University of Colorado

Tom A. Ranker

University of Colorado at Boulder

Paul Stephen Corn

Aldo Leopold Wilderness Research Institute

Richard G. Olmstead

University of Colorado at Boulder

Follow this and additional works at: https://digitalcommons.unl.edu/usgsstaffpub

Part of the Earth Sciences Commons

Goebel, Anna M.; Ranker, Tom A.; Corn, Paul Stephen; and Olmstead, Richard G., "Mitochondrial DNA evolution in the Anaxyrus boreas species group" (2008). USGS Staff -- Published Research. 102.

https://digitalcommons.unl.edu/usgsstaffpub/102

This Article is brought to you for free and open access by the US Geological Survey at DigitalCommons@University of Nebraska - Lincoln. It has been accepted for inclusion in USGS Staff -- Published Research by an authorized administrator of DigitalCommons@University of Nebraska - Lincoln. 


\title{
Mitochondrial DNA evolution in the Anaxyrus boreas species group
}

\author{
Anna M. Goebel ${ }^{\mathrm{a}, \mathrm{b}, *}$, Tom A. Ranker ${ }^{\mathrm{c}, 1}$, Paul Stephen Corn ${ }^{\mathrm{d}}$, Richard G. Olmstead ${ }^{\mathrm{e}, 2}$ \\ ${ }^{a}$ University of Colorado Museum of Natural History, 265 UCB, University of Colorado, Boulder, CO 80309-0265, USA \\ ${ }^{\mathrm{b}}$ Florida Gulf Coast University, Department of Biological Sciences, Fort Myers, FL 33965, USA \\ ' University of Colorado Museum of Natural History, Department of Ecology and Evolutionary Biology, University of Colorado, Boulder, CO 80309, USA \\ ${ }^{\mathrm{d}}$ USGS Northern Rocky Mountain Science Center, Aldo Leopold Wilderness Research Institute, 790 E. Beckwith Avenue, Missoula, MT 59801, USA \\ ${ }^{\text {e }}$ E.P.O. Biology Department, University of Colorado, Boulder, CO 80309, USA
}

\section{A R T I C L E I N F O}

\section{Article history:}

Received 1 May 2007

Revised 10 June 2008

Accepted 24 June 2008

Available online 8 July 2008

\section{Keywords:}

Amphibia

Anura

Bufonidae

Anaxyrus boreas

Bufo

boreas

halophilus

nelsoni

canorus

exsul

Restriction sites

Control region

Cytochrome oxidase I

12S rDNA

Phylogeography

Conservation

\begin{abstract}
A B S T R A C T
The Anaxyrus boreas species group currently comprises four species in western North America including the broadly distributed A. boreas, and three localized species, Anaxyrus nelsoni, Anaxyrus exsul and Anaxyrus canorus. Phylogenetic analyses of the mtDNA 12S rDNA, cytochrome oxidase I, control region, and restriction sites data, identified three major haplotype clades. The Northwest clade (NW) includes both subspecies of $A$. boreas and divergent minor clades in the middle Rocky Mountains, coastal, and central regions of the west and Pacific Northwest. The Southwest (SW) clade includes A. exsul, A. nelsoni, and minor clades in southern California. Anaxyrus canorus, previously identified as paraphyletic, has populations in both the NW and SW major clades. The Eastern major clade (E) includes three divergent lineages from southern Utah, the southern Rocky Mountains, and north of the Great Basin at the border of Utah and Nevada. These results identify new genetic variation in the eastern portion of the toad's range and are consistent with previous regional studies from the west coast. Low levels of control region sequence divergence between major clades (2.2-4.7\% uncorrected pair-wise distances) are consistent with Pleistocene divergence and suggest that the phylogeographic history of the group was heavily influenced by dynamic Pleistocene glacial and climatic changes, and especially pluvial changes, in western North America. Results reported here may impact conservation plans in that the current taxonomy does not reflect the diversity in the group.
\end{abstract}

(c) 2008 Elsevier Inc. All rights reserved.

\section{Introduction}

Historical classifications of toads (Amphibia: Bufonidae) recognized species groups based on morphological similarity. Blair (1972b,c) identified at least 37 species groups in the genus Bufo (Laurenti, 1768) from the approximately 200 species recognized at that time and placed the North American toads into seven species groups (boreas, punctatus, retiformis, debilis, quercicus, cognatus, americanus). Collectively these groups comprise the Nearctic toads,

\footnotetext{
* Corresponding author. Current address: Florida Gulf Coast University, Department of Biological Sciences, 10501 FGCU Boulevard South, Fort Myers, FL 33965 USA. Fax: +1 2395907200.

E-mail addresses: agoebel@fgcu.edu (A.M. Goebel), ranker@hawaii.edu (T.A. Ranker), scorn@usgs.gov (P.S. Corn), olmstead@u.washington.edu (R.G. Olmstead).

1 Present address: University of Hawai'i at Manoa, Department of Botany, 3190 Maile Way, St. John 101, Honolulu, HI 96822, USA.

2 Present address: Department of Biology, Box 355325, University of Washington, Seattle, WA 98195, USA.
}

genus Anaxyrus (Tschudi, 1845; Frost et al., 2006a). Relationships within groups are less clear than group identity, and cryptic speciation has long been recognized as a problem in toads (Blair, 1972b). More recently, mitochondrial DNA has been used to identify relationships within those groups and all studies have identified highly divergent toad lineages not recognized by taxonomy (Graybeal, 1993; Shaffer et al., 2000; Stephens, 2001; Masta et al., 2002; Smith and Green, 2004; Jaeger et al., 2005).

The boreas species group, as currently recognized (Stebbins, 2003; Frost, 2007), is comprised of two subspecies broadly distributed across North America and three species with localized distributions (Fig. 1). Anaxyrus boreas (Baird and Girard, 1852) is found from the east slope of the Rocky Mountains to the Pacific Ocean and from northern Baja California to Alaska and the Yukon. The subspecies A. b. boreas (Baird and Girard, 1852) occupies most of this range, but $A$. b. halophilus (Baird and Girard, 1853) occurs on the West Coast from northern California to Baja California. The subspecies are thought to be sympatric in northern California 


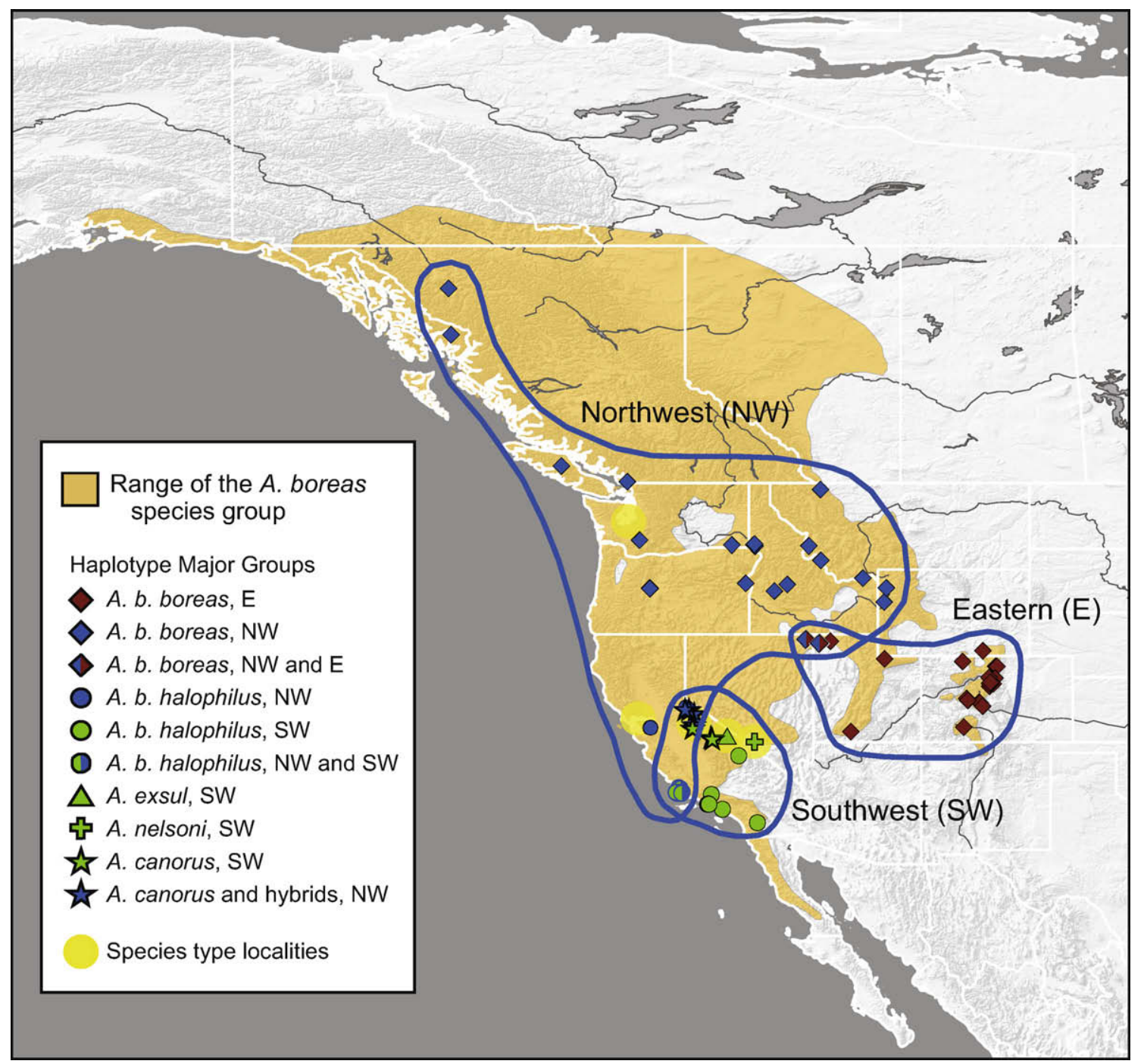

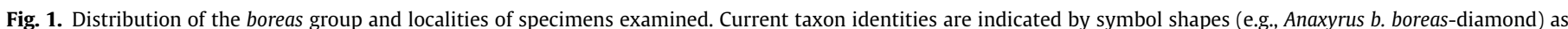

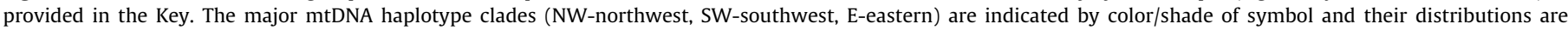

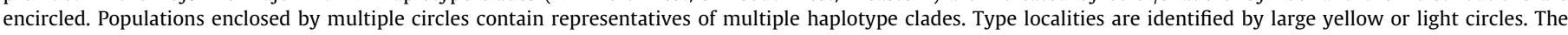

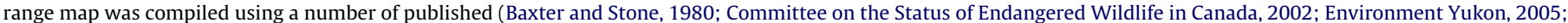

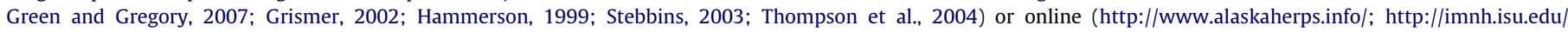
digitalatlas; http://www.wdfw.wa.gov/wlm/gap/dataprod.htm) sources and expert advice.

(Camp, 1917a; Stebbins, 2003). The other three species are considered Pleistocene relicts (Myers, 1942; Karlstrom, 1958, 1962). Anaxyrus exsul (Myers, 1942) occurs only in Deep Springs Valley of east central California (Fellers, 2005). Anaxyrus nelsoni (Stejneger, 1893) is currently known only in the Amargosa River drainage of southwestern Nevada (Altig and Dodd, 1987; Goebel et al., 2005). Anaxyrus canorus (Camp, 1916) is narrowly distributed at high elevations in the Sierra Nevada and is sympatric with $A$. boreas at the northern end of its distribution (Karlstrom, 1962; Morton and Sokoloski, 1978; Davidson and Fellers, 2005).

Morphological characters that distinguish some boreas group taxa are striking (e.g., the black coloration of $A$. exsul contrasts brown color typical of toads), but morphological variation within the group is limited (Karlstrom, 1962; Myers, 1942). Schuierer (1963), Burger and Bragg (1946), and Karlstrom (1962), noted that specimens in Colorado and/or Alaska were morphologically different (e.g., smaller size, smoother skin, more pronounced warts) from toads in the more coastal northwest, but Karlstrom (1962) found these same characters to vary with age, sex and elevation and did not consider them diagnostic. Other unusual forms were noted in Montana, and Alberta (Black, 1970, 1971; Schueler, 1982). Sanders and Cross (1963), noted chromosomal differences between $A$. b. boreas in Colorado and $A$. b. halophilus in California but early chromosomal data are difficult to interpret due to the limited techniques available at the time. However, these comments suggest the possibility of cryptic speciation.

All previous molecular phylogenetic analyses that include members of the boreas group were either regional studies that examined a small portion of the toad's range on the west coast and western Nevada (Feder, 1973; Graybeal, 1993; Shaffer et al., 2000; Stephens, 2001; Simandle, 2006; Simandle et al., 2006) or were phylogenetic analyses of deeper relationships among toads and frogs that included few specimens of the boreas group (Maxson et al., 1981; Graybeal, 1997; Macey et al., 1998; Darst and Cannatella, 2004; Pauly et al., 2004; Goebel, 1996, 2005; Pramuk, 2006; Frost et al., 2006a). Molecular analyses of the group are further complicated because the species are recently diverged and quite distant from potential outgroups (Pauly et al., 2004; Pramuk, 2006; Frost et al., 2006a) making rooting by outgroups difficult (Wheeler, 1990; Huelsenbeck et al., 2002). Non-molecular phylo- 
genetic studies that included specimens of the group similarly focused only on deeper relationships of bufonids (Karlstrom, 1962; Tihen, 1962; Schuierer, 1963; Blair, 1963, 1964, 1972b; Bogart, 1972; Sanders and Cross, 1963; Graybeal, 1997).

Our goal was to provide a broader molecular analysis of the boreas group. By examining mtDNA of all taxa and toads from across the distribution, we hoped to put the regional studies into a larger context and to examine diversity within the whole group. We specifically wanted to include specimens from the eastern portion of the range as these were not included in previous analyses. Toads from the Southern Rocky Mountain Population (SRMP: Colorado and a few localities in south central Wyoming and northern New Mexico) were of special concern due to declines that probably began in the 1970's (Corn, 2003; Muths and Nanjappa, 2005). The SRMP is listed as endangered by the State of Colorado (Hammerson, 1999), but was removed as a candidate species for listing by the US Endangered Species Act in 2006 in part due to a lack of genetic distinction (Thompson, 2005). The combination of potential morphological divergence of the SRMP from the rest of the group (Schuierer, 1963; Burger and Bragg, 1946; Karlstrom, 1962), a disjunct distribution (Fig. 1), and recent declines, suggested a need for a phylogenetic analysis that included toads from the SRMP in Colorado. To identify relationships among more divergent lineages, we analyzed slowly evolving genes (12S ribosomal DNA and a portion of cytochrome oxidase I) and rapidly evolving DNA data (the control region and restriction sites of the whole mtDNA) with parsimony and Bayesian analyses.

\section{Materials and methods}

\subsection{Data collection and alignment}

Specimens (288 individuals from 58 sites, Table 1 and Fig. 1) were collected from all currently recognized taxa and throughout much of the range of the boreas group (Fig. 1). Specimens were chosen from localities where taxa exist in isolation whenever possible, because hybridization was suspected among some taxa (Karlstrom, 1962; Morton and Sokoloski, 1978; Mullally and Powell, 1958). All taxon identities were determined by collectors using morphology (hybrids were determined by intermediate morphological characteristics) and range maps (Stebbins, 2003). Thirteen species of Anaxyrus with varying levels of divergence from the boreas group were included as outgroups along with species of Ollotis (Frost et al., 2006b) and Chaunus (also called Rhinella, Chaparro et al., 2007) as further outgroups (Graybeal, 1997; Pramuk et al., 2001; Pauly et al., 2004; Pramuk, 2006; Frost et al., 2006a). Locality information, voucher identity, number of samples from each locality, restrictions site haplotype numbers and GenBank accession numbers for sequences, are in Table 1. Total DNA was extracted from tissue using standard phenol extraction and proteinase $\mathrm{K}$ digestion (Maniatis et al., 1982) or with either the DNeasy Tissue or QIAamp DNA Blood Mini Kits (Qiagen Inc., Valencia CA). Restriction site polymorphisms of the whole mtDNA molecule were identified using standard techniques (Southern, 1975; Maniatis et al., 1982; Koetsier et al., 1993). Genomic DNA was cut with 16 six-base cutting restriction enzymes (ApaI, BamHI, BglI, BglII, ClaI, Csp45I, DraI, EcoRI, EcoRV, KpnI, NheI, PstI, PvuII, SmaI, StuI and XhoI). After digestion, fragments were separated by size with agarose gel electrophoresis, transferred to nylon membranes, and probed with four fragments comprising the complete mtDNA of Chaunus marinus (syn. Bufo marinus). Restriction sites were mapped (Goebel, 1996) using double digests and serial probing with the four mtDNA fragments.

Sequences of the control region (CR) cytochrome oxidase I (COI), and $12 \mathrm{~S}$ ribosomal DNA (12S) were determined with ampli- fication and sequencing methods described by Goebel et al. (1999). The $12 \mathrm{~S}$ was amplified using four primers (12SA-L, Kocher et al., 1989; tRNAphe-L, 12SF-H, tRNAval-H, Goebel et al., 1999). COI sequences were obtained using two primers (CO1e-H, Palumbi et al., 1991; CO1af-L, Goebel et al., 1999) and CR sequences were determined using six primers (CytbA-L, ControlJ-L, ControlK-H, ControlO-H, ControlP-H; Wrev-L, Goebel et al., 1999). The primer ControlP2-H (5'-CATAGATTCASTTCCGTCAGATGCC-3') was located six bases internal to ControlP-H and was used for sequencing because it provided superior data compared to the terminal amplification primer ControlP-H. For outgroups, $537 \mathrm{bp}$ of the $3^{\prime}$ end of the control region $\left(\mathrm{CR}_{537}\right)$ were obtained using a combination of four primers (Wrev-L, Control J-L, ControlB-H, ControlP-H; Goebel et al., 1999). Sequences of both strands were obtained for all $12 \mathrm{~S}$ and $\mathrm{COI}$ sequences and at least one accession of all unique CR sequences.

Data were collected in a hierarchical fashion. Restriction sites (RS) were collected initially from all specimens available before 1995 and 31 haplotypes were identified. An 882 bp fragment of $\mathrm{CR}\left(\mathrm{CR}_{882}\right)$ was obtained for all unique RS haplotypes in each population (collection site or set of geographically close sites) even when the same RS haplotype occurred in multiple populations. Sequences were also obtained for most $A$. exsul, A. nelsoni and A. canorus available. Sequences from $12 \mathrm{~S}$ and COI were obtained from the more divergent haplotypes initially identified with RS and CR and from at least two accessions of all named taxa. For samples added after all RS data were collected the $\mathrm{CR}_{537}$ fragment was sequenced first. Then the additional $355 \mathrm{bp}$ (the full $\mathrm{CR}_{882}$ ) fragment was obtained from all unique $\mathrm{CR}_{537}$ haplotypes in each population. Sequence data assisted in refining restriction site maps. After identification of insertions, deletions, and repeated regions in the $\mathrm{CR}$, restriction sites that mapped close to the repeated regions were re-scored or excluded from the analysis if they could not be identified with confidence in all samples.

Sequences were aligned manually. Within the boreas group, gaps due to insertions/deletions occurred as single bases with only a few exceptions. A 7-bp gap was found in the $5^{\prime}$ end of $\mathrm{CR}_{882}$ in samples from two geographically close sites (Teton Co., WY and Beaverhead Co., MT). The rarity of the deletion and its limited geographic distribution suggest it was a single evolutionary event and it was scored as a single gap. Several larger (163-173 bp) unique repeated regions and a common 21-bp repeated fragment were found within the $5^{\prime}$ end of $\mathrm{CR}_{882}$ also and were excluded from analyses. Sequence alignments of $12 \mathrm{~S}$ and $\mathrm{CR}_{537}$ partitions with outgroup taxa were more ambiguous due to multiple adjacent gaps and those sites were deleted from analyses (6 sites from 12S, 149 from $\mathrm{CR}_{537}$ ). Only unique haplotypes were included in analyses. Alignments were deposited in TreeBase (Study accession number $=$ S2194, Matrix accession number $=$ M4155-M4161).

\subsection{Data analysis}

The four data partitions (12S, COI, CR, RS) were first assessed separately. Data for the control region were analyzed both for the larger $\mathrm{CR}_{882}$ fragment and the smaller $\mathrm{CR}_{537}$ fragment, because $\mathrm{CR}_{537}$ was obtained for many more specimens. The protein-coding gene COI was not partitioned further in analyses of the boreas group because there were no second position changes, only two first position changes, and no amino acid substations. In exploratory analyses of $\mathrm{COI}$ with outgroups data were partitioned further into first positions ( 11 variable positions) and third positions (there were no second position changes and no amino acid substitutions) but the additional partitioning did not affect rooting position or relationships within the boreas group, so COI data were not partitioned further in final analyses. 


\begin{tabular}{|c|c|c|c|c|c|c|c|c|c|c|}
\hline \multirow{3}{*}{$\begin{array}{l}\text { Taxon locality(s) } \\
\text { Anaxyrus boreas boreas }\end{array}$} & \multirow[t]{2}{*}{ Voucher } & \multirow{2}{*}{$\begin{array}{l}\text { Locality } \\
\text { code }\end{array}$} & \multirow{2}{*}{$\begin{array}{l}\text { Number of } \\
\text { samples }(n=288)\end{array}$} & \multirow{2}{*}{$\begin{array}{l}\text { RS haplotype } \\
(n=194)\end{array}$} & \multicolumn{6}{|c|}{ GenBank Accession Nos. for sequence data } \\
\hline & & & & & \multicolumn{2}{|c|}{$\mathrm{CR}_{882}(n=117)$} & \multicolumn{2}{|c|}{$\mathrm{CR}_{537}(n=52)$} & \multirow[t]{2}{*}{$\mathrm{COI}(n=50)$} & \multirow[t]{2}{*}{$12 S(n=22)$} \\
\hline & & & & & & & & & & \\
\hline \multirow[t]{3}{*}{ Kane Co., UT, 3 sites } & USNMFT211044-8 & KaUT & 17 & $1(9)$ & EF532065 & EF532070 & EF532068 & EF532073 & EF532015 & EF531993 \\
\hline & USNMFT064347 & & & & EF532066 & & EF532069 & EF532074 & EF532016 & EF531994 \\
\hline & USNMFT18024-9 & & & & EF532067 & & EF532071 & EF532072 & EF532017 & \\
\hline \multirow{3}{*}{$\begin{array}{l}\text { Box Elder Co., UT, Red Butte Canyon, Upper Rocky } \\
\text { Pass Spring, Lynn Reservoir }\end{array}$} & & BEUT & 7 & - & EF532075 & EF532080 & EF532078 & & EF532018 & EF531995 \\
\hline & & & & & EF532076 & EF532112 & EF532079 & & EF532019 & \\
\hline & & & & & EF532077 & & & & EF532038 & \\
\hline Summit Co., UT, East Fork of Bear River & USNMFT211041 & SuUT & 1 & $2(1)$ & EF532082 & & & & EF532020 & EF531996 \\
\hline \multirow{2}{*}{ Elko Co., NV } & AMG554 & EINV & 3 & - & EF532081 & EF532101 & & & EF532032 & \\
\hline & & & & & EF532100 & & & & & \\
\hline \multirow{2}{*}{$\begin{array}{l}\text { Larimer Co., CO, Rocky Mountain NP Lost Lake and } \\
\text { Kettle Tarn }\end{array}$} & USNMFT064334 & LaCO & 23 & $3(16)$ & EF532084 & EF532094 & & & EF532022 & EF531997 \\
\hline & AMG138 & & & $4(1), 5(3)$ & EF532092 & & & & EF532028 & \\
\hline \multirow{2}{*}{$\begin{array}{l}\text { Gunnison Co., CO, near Crested Butte White Rock } \\
\text { Basin and West Brush Creek }\end{array}$} & & GuCO & 3 & $3(2), 4(1)$ & EF532089 & & & & EF532026 & EF531998 \\
\hline & & & & & EF532090 & & & & EF532027 & \\
\hline Summit Co., CO, near Montezuma & AMG027 & SuCO & 4 & $3(4)$ & EF532086 & & & & EF532024 & \\
\hline \multirow{2}{*}{$\begin{array}{l}\text { Chaffee Co., CO, Brown Creek, Collegiate Peaks Cpgd } \\
\text { Denny Creek and Hartenstein Lake }\end{array}$} & USNMFT064330 & ChCO & 27 & $3(19)$ & EF532085 & & & & EF532023 & \\
\hline & & & & $4(8)$ & EF532088 & & & & EF532025 & \\
\hline Albany Co., WY; SW Medicine Bow NP & & AIWY & 2 & $3(2)$ & EF532083 & & & & EF532021 & \\
\hline Route Co., CO; First Creek & & RoCO & 2 & $3(2)$ & EF532091 & & & & & \\
\hline \multirow{2}{*}{$\begin{array}{l}\text { Clear Creek Co., CO; Henderson Region, Georgetown, } \\
\text { Bethyl Creek }\end{array}$} & & CCCO & 20 & $3(7)$ & EF532095 & EF532098 & & & EF532030 & \\
\hline & & & & $4(7), 5(6)$ & EF532097 & EF532099 & & & EF532031 & \\
\hline Boulder Co., CO Indian Peaks Wilderness & USNMFT211037 & BoCO & 4 & $3(2), 5(2)$ & EF532093 & EF532096 & & & EF532029 & \\
\hline Mineral Co., CO, Cliff Creek & AMG544A & $\mathrm{MiCO}$ & 1 & - & EF532087 & & & & & \\
\hline \multirow{4}{*}{ Deschutes Co., OR, near Three Creeks Lake } & USNMFT211042 & DeOR & 10 & $6(4), 10(1)$ & EF532102 & EF532127 & & & EF532036 & EF532006 \\
\hline & & & & $11(1), 12(1)$ & EF532108 & EF532136 & & & EF532044 & EF532007 \\
\hline & & & & $17(1), 21(1)$ & EF532109 & EF532138 & & & EF532048 & \\
\hline & & & & $22(1)$ & EF532110 & & & & EF532049 & \\
\hline Surrey, British Columbia, Latimer Lake & MVZ178495,178498, & SuBC & 4 & $6(2), 8(2)$ & EF532103 & EF532107 & & & EF532033 & \\
\hline & 178500,501 & & & & EF532106 & & & & EF532035 & \\
\hline Vancouver Isle, British Columbia & AMG355 & VaBC & 3 & $7(3)$ & EF532104 & EF532105 & & & EF532034 & EF531999 \\
\hline Columbia Co., WA, N. Fork Touchet River & MJA:AMG112 & CoWA & 1 & $13(1)$ & EF532116 & & & EF532040 & EF532001 & \\
\hline Skamania Co., WA, Mt. St. Helens & MSB 92531-92538 & SkWA & 8 & - & EF532146 & & EF532148 & EF532152 & EF532052 & \\
\hline & & & & & EF532147 & & EF532150 & EF532153 & & \\
\hline & & & & & EF532149 & & EF532151 & & & \\
\hline Glacier Co., MT, Glacier NP & USNMFT211007-9 & GIMT & 4 & $13(1)$ & EF532180 & & EF532181 & & & \\
\hline & & & & & EF532117 & & EF532182 & & & \\
\hline Ravali Co., MT, Kramis Pond & BSFS18016-18023 & RaMT & 8 & - & EF532183 & EF532187 & EF532185 & & EF532055 & \\
\hline & & & & & EF532184 & EF532189 & EF532188 & & & \\
\hline & & & & & EF532186 & & EF532190 & & & \\
\hline $\begin{array}{l}\text { Beaverhead Co., MT, Red Rocks NWR and Twin Lakes, } \\
\text { Beaverhead NF }\end{array}$ & AMG033 & BeMT & 9 & $13(5)$ & EF532124 & & & & EF532039 & \\
\hline & & & & $15(4)$ & EF532113 & EF532119 & & & EF532041 & \\
\hline Teton Co., WY, Yellowstone NP, and Jackson Hole & USNMFT211036 & TeWY & 8 & $13(4)$ & EF532118 & EF532123 & & & EF532042 & EF532002 \\
\hline & & & & $14(1)$ & EF532120 & EF532125 & & & EF532043 & \\
\hline & & & & $15(2)$ & EF532121 & EF532126 & & & & \\
\hline & & & & $16(1)$ & EF532122 & & & & & \\
\hline $\begin{array}{l}\text { Nez Perce Co., ID, Mud Bog Meadows, China Creek, } \\
\text { and Benton Meadows }\end{array}$ & USNMFT064339 & NPID & 5 & $9(5)$ & EF532111 & EF532115 & & & EF532037 & EF532000 \\
\hline & & & & & EF532114 & & & & & \\
\hline Washington Co., ID, Grouse Creek & AMG541 & WaID & 8 & - & EF532154 & EF532158 & EF532155 & EF532159 & EF532053 & \\
\hline & & & & & EF532156 & EF532160 & EF532157 & EF532161 & & \\
\hline
\end{tabular}




\begin{tabular}{|c|c|c|c|c|c|c|c|c|c|c|}
\hline \multirow[t]{3}{*}{ Boise Co., ID, Missouri Mines } & \multirow[t]{3}{*}{ AMG532 } & \multirow[t]{3}{*}{ BoID } & \multirow[t]{3}{*}{9} & \multirow[t]{3}{*}{-} & EF532163 & \multirow[t]{3}{*}{ EF532167 } & EF532162 & EF532170 & \multirow[t]{3}{*}{ EF532054 } & \\
\hline & & & & & EF532164 & & EF532165 & EF532169 & & \\
\hline & & & & & EF532166 & & EF532168 & & & \\
\hline \multirow[t]{3}{*}{ Boise Co., ID. Bull Trout Lake } & \multirow[t]{3}{*}{ AMG554 } & \multirow[t]{3}{*}{ BolD } & \multirow[t]{3}{*}{9} & \multirow[t]{3}{*}{-} & EF532172 & & EF532171 & EF532176 & & \\
\hline & & & & & EF532174 & & EF532173 & EF532177 & & \\
\hline & & & & & EF532178 & & EF532175 & EF532179 & & \\
\hline \multirow[t]{8}{*}{ Alaska, Chickamon Rivers } & \multirow[t]{8}{*}{ AMG633 } & \multirow[t]{8}{*}{ ChAK, } & \multirow[t]{8}{*}{19} & \multirow[t]{9}{*}{-} & EF532193 & & EF532191 & EF532203 & \multirow[t]{9}{*}{ EF532056 } & \\
\hline & & & & & EF532196 & & EF532192 & EF532204 & & \\
\hline & & & & & EF532197 & & EF532194 & EF532205 & & \\
\hline & & & & & & & EF532195 & EF532206 & & \\
\hline & & & & & & & EF532198 & EF532207 & & \\
\hline & & & & & & & FF532199 & EF532208 & & \\
\hline & & & & & & & EF532200 & EF532209 & & \\
\hline & & & & & & & EF532201 & EF532202 & & \\
\hline British Columbia, Little Tahltan River & & LTBC & 2 & & & & EF532210 & EF532211 & & \\
\hline Anaxyrus boreas halophilus & & & & & & & & & & \\
\hline Inyo Co., CA, Darwin Canyon & MVZ178484-9 & InCA & 6 & $27(2), 28(2)$ & EF532218 & EF532220 & & & EF532061 & EF532012 \\
\hline & & & & $29(2)$ & EF532219 & EF532221 & & & & \\
\hline Mariposa Co., CA, Yosemite NP & Shaffer et al. $(2000)^{c}$ & MaCA & 1 & & EF532230 & & & & & \\
\hline Santa Clara Co., CA & DM:AMG294 & SCCA & 1 & $22(1)$ & & & EF532137 & & & \\
\hline Ventura Co., CA, Piru and Santa Monica Mts & UCSB29622-29623 & VeCA & 5 & $29(4), 30(1)$ & EF532224 & & & & EF532063 & EF532013 \\
\hline Los Angeles Co., CA Santa Monica Mts and California & UCSB29624-29625 & LACA & 3 & $29(3)$ & EF532222 & & & & & \\
\hline & ROM21064 & & & & & & & & & \\
\hline Santa Barbara Co., Santa Maria and Lompac to & UCSB29619-29621 & SBCA & 16 & $21(1)$ & EF532144 & EF532223 & & & EF532062 & \\
\hline & UCSB29626-29637 & & & $20(13)$ & EF532145 & & & & & \\
\hline & & & & $25(1), 31(1)$ & EF532226 & & & & & \\
\hline Alpine Co, CA, Eldorado NF, Little Indian Valley & DM:AMG286 & AICA & 5 & $6(1), 19(4)$ & EF532128 & EF532129 & & & & \\
\hline San Diego Co., CA, S. of Warner Springs & & SDCA & 6 & $29(6)$ & EF532225 & EF532227 & & & EF532064 & EF532014 \\
\hline Contra Costa Co., Corrall Hollow Road & MVZ186282-8 & CCCA & 7 & $23(6)$ & EF532139 & EF532142 & & & EF532050 & \\
\hline & & & & $24(1)$ & EF532140 & EF532143 & & & EF532051 & \\
\hline & & & & & F532141 & & & & & \\
\hline Anaxyrus exsul & & & & & & & & & & \\
\hline Inyo Co, CA, Buckhorn Spring & MVZ142943-142947 & InCA & 5 & $26(5)$ & EF532212 & EF532214 & & & EF532057 & EF532008 \\
\hline & & & & & EF532213 & EF532215 & & & EF532058 & EF532009 \\
\hline Anaxyrus nelsoni & & & & & & & & & & \\
\hline Nye Co., NV, Crystal Springs & KH:AMG167-8 & NyNV & 2 & $27(2)$ & EF532216 & & & & EF532059 & EF532010 \\
\hline & & & & & EF532217 & & & & EF532060 & EF532011 \\
\hline Anaxyrus canorus & & & & & & & & & & \\
\hline Mono Co., CA, Sonora Pass & MVZ164900-02 & MoCA & 3 & $18(3)$ & EF532130 & EF532132 & & & EF532045 & EF532003 \\
\hline & & & & & EF532131 & & & & EF532046 & EF532004 \\
\hline Alpine Co., Co., CA, Tryon Medow & DM:AMG293 & AICA & 2 & $19(1), 20(1)$ & EF532133 & & & & EF532047 & EF532005 \\
\hline Mariposa Co., CA, Yosemite NP & Shaffer et al. (2002) ${ }^{\mathrm{a}}$ & MaCA & 2 & - & EF532228 & EF532232 & & & & \\
\hline Fresno Co., Kings Canyon NP & Shaffer et al. $(2002)^{\mathrm{b}}$ & FrCA & 3 & - & EF532229 & EF532233 & & & & \\
\hline & & & & & EF532231 & & & & & \\
\hline A. canorus $X$ A. boreas & & & & & & & & & & \\
\hline Alpine Co., CA, Wheeler Lake & DM:AMG291-2 & AICA & 2 & $6(1), 19(1)$ & EF532134 & EF532135 & & & & \\
\hline Outgroups & & & & & & & & & & \\
\hline Anaxyrus hemiophrys(Manitoba, Canada) & DMG4337 & - & 1 & - & - & & EF532270 & & EF532252 & EF532234 \\
\hline Anaxyrus americanus (Ontario, Canada) & ROM21661 & - & 1 & - & - & & EF532271 & & EF532253 & EF532235 \\
\hline Anaxyrus houstonensis (Texas, USA) & AHPFS3095 & - & 1 & - & - & & EF532272 & & EF532254 & EF532236 \\
\hline Anaxyrus woodhousii (Colorado, USA) & AMG-1 & - & 1 & - & - & & EF532273 & & EF532255 & EF532237 \\
\hline & & & & & & & & & (continuec & next page) \\
\hline
\end{tabular}




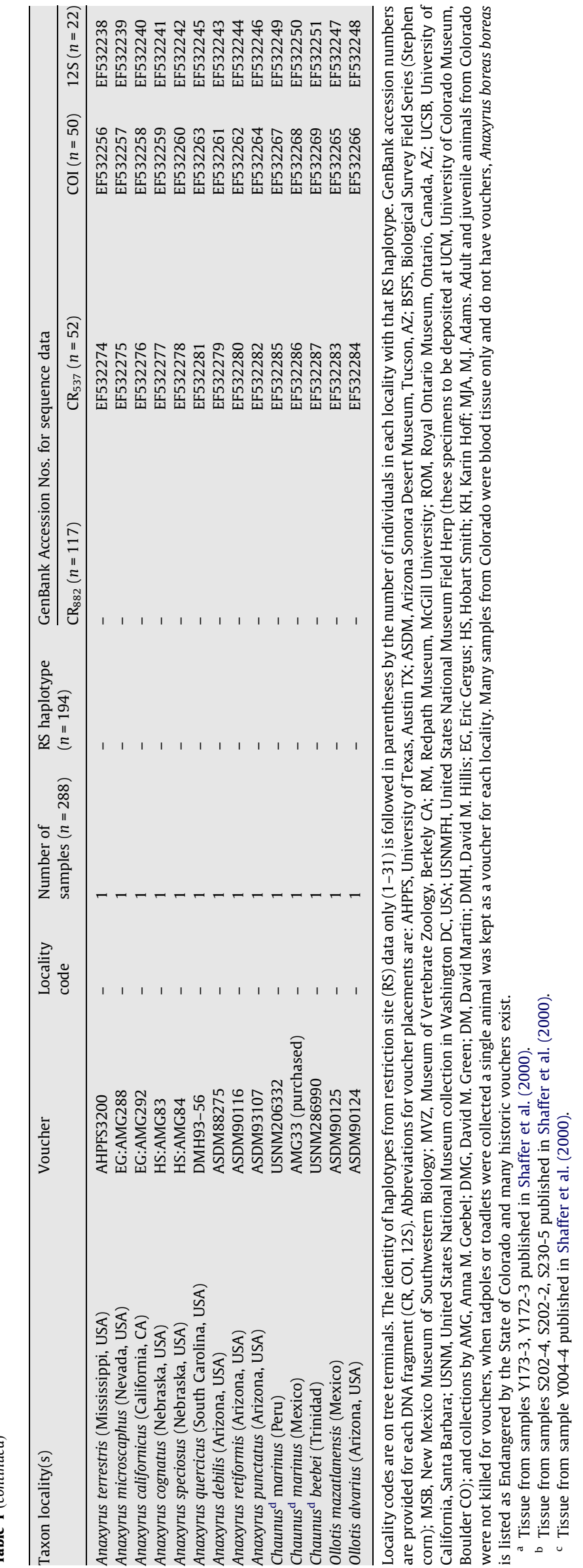

The data partitions were combined in two ways so that only samples with all data were included in analyses. The first combination included 22 samples for which four partitions $\left(12 \mathrm{~S} / \mathrm{COI} / \mathrm{CR}_{882} /\right.$ $\mathrm{RS})$ were available. The second combination included 44 samples from three partitions $\left(\mathrm{COI} / \mathrm{CR}_{882} / \mathrm{RS}\right)$. By excluding $12 \mathrm{~S}$ from this combination, the number of samples was doubled and few informative sites were excluded. Because RS data were collected from the whole mtDNA, overlap between RS and sequence data was identified at ten restriction sites (DNA Strider 1.01, Christian Marck). In phylogenetic analyses with multiple partitions restriction sites, found within sequenced regions, were excluded.

In order to compare the utility of the partitions, 22 samples with all data types were examined with independent analyses for each partition (trees not shown). Utility was first assessed by estimating the number of unique haplotypes and variable characters in each partition, because variable markers are critical for examining differentiation within and among closely related populations. A second measure of utility, the proportion of parsimony informative characters per total length of alignment, was also calculated. A larger number of parsimony informative characters does not necessarily result in greater resolution, or support for clades, but we include it as a first measure to estimate efficiency of data collection.

Maximum parsimony (MP) methods were used to generate phylogenetic hypotheses using PAUP* (Swofford, 2002). Parsimony analyses were conducted on each partition and on the two combined datasets. Two MP analyses were conducted per partition (RS, CO1, $\mathrm{CR}_{882}, \mathrm{CR}_{537}, 12 \mathrm{~S}$ ), one with all characters weighted equally and a second with all characters weighted on the re-scaled consistency index (RCI). Transversions and transitions were treated equally and gaps were weighted equally with substitutions (Ogden and Rosenberg, 2007). Heuristic searches were performed using tree bisection-reconnection (TBR) branch-swapping and using the steepest descent option. One million random addition sequence replicate searches were performed for all analyses. Due to the large number of trees in RS analyses, only three trees were saved per replicate. Nodal support for all parsimony analyses was assessed using non-parametric bootstrapping (Felsenstein, 1985), which was computed from $10^{4}$ replicates using a heuristic search, TBR branch-swapping and saving 100 random addition sequence replicates per replicate.

Bayesian methods were also used to generate phylogenetic hypotheses for all partitions of the data, and the two combined datasets. Appropriate models for sequence evolution were explored (Modeltest 3.7, Posada and Crandall, 1998; Mr. Modeltest 2.2, Nylander, 2004). However, there was uncertainty surrounding model choice for ingroup analyses because different models were chosen with hierarchical likelihood ratio tests (hLRT), the Akaike Information Criterion (AIC and AICc; Akaike, 1974), and Bayesian Information Criterion (BIC and BICc, Schwarz, 1978), especially for the smaller data sets. Models for final analyses were based on the model chosen by AIC. However, exploratory analyses using the alternate models were examined for conflict in topology and variation in support levels. For the RS data a single substitution rate (nst $=1$ ) and a proportion of invariant sites (rates = propinv) was used. The presence of invariant sites (coding = noabsence) allowed the data set to have some cutting sites in all samples. For analyses of combined data sets, the models chosen for individual partitions were used and the partitions were unlinked. The relative rates were also unlinked by setting the rate prior to 'variable'.

Bayesian analyses were conducted using MrBayes 3.1.2 (Ronquist and Huelsenbeck, 2003; Huelsenbeck and Ronquist, 2005). For both exploratory and final analyses two simultaneous runs were conducted from random starting trees using four Markov chains (one cold, three heated, temperature of 0.2 ). In shorter exploratory analyses, five million generations were run and trees 
Table 2

Data description for data partitions and combinations of partitions for the boreas group

\begin{tabular}{|c|c|c|c|c|c|c|c|}
\hline \multirow[t]{2}{*}{ Data description } & \multicolumn{5}{|c|}{ Single partitions } & \multicolumn{2}{|l|}{ Partition combinations } \\
\hline & $12 \mathrm{~S}$ & $\mathrm{COI}$ & $\mathrm{CR}_{882}$ & $\mathrm{CR}_{537}$ & RS & All data: $12 \mathrm{~S} / \mathrm{COI} / \mathrm{CR}_{882} / \mathrm{RS}$ & Three partitions $\mathrm{COI} / \mathrm{CR}_{882} / \mathrm{RS}$ \\
\hline Number samples & 22 & 50 & 117 & 169 & 194 & 22 & 44 \\
\hline Length of alignment & 890 & 394 & 882 & 537 & 60 sites $^{a}$ & 2226 & 1336 \\
\hline Number unique haplotypes & 15 & 18 & 59 & 45 & 31 & 19 & 40 \\
\hline Number variable characters ${ }^{b}$ & 25 & 27 & 115 & 100 & 30 & 154 & 141 \\
\hline Number parsimony informative characters ${ }^{b}$ & 18 & 19 & 91 & 76 & 22 & 111 & 106 \\
\hline Consistency index & 0.90 & 0.80 & 0.69 & 0.66 & 0.68 & 0.78 & 0.73 \\
\hline Rescaled consistency index & 0.78 & 0.72 & 0.61 & 0.58 & 0.58 & 0.69 & 0.68 \\
\hline Range of uncorrected $p$-distances (no gaps) & $1.1-0.0$ & $3.3-0.3$ & $4.7-0.1$ & $6.0-0.2$ & - & $2.6-0.0$ & $3.8-0.0$ \\
\hline
\end{tabular}

a The 60 restriction sites represent $360 \mathrm{bp}$; restriction enzymes recognized six bases at each cutting site.

b A character consists of a DNA base or restriction site.

were sampled every 400 generations. The program Tracer 1.4 (Rambaut and Drummond, 2007) was used to assess stationarity by examining plots of all parameter values against generation, convergence was assessed by comparing the values across four runs (two exploratory and two final). Analyses suggested that both stationarity and convergence were achieved for all individual and combined partitions of the data very early (within 500,000 generations all ingroup analyses and one million generations for analyses with outgroups). In the exploratory analyses we set a very conservative burnin of four million generations on the two runs which yielded 5000 trees total. In final analyses 20 million generations were run, trees were sampled every 1000 generations and burnin was set at five million generations yielding 30,000 trees total. These trees were used to create a majority rule consensus tree (FigTree, Rambaut, 2008) as shown in figures.

Two approaches were used to identify a root within the boreas group. Outgroup rooting was conducted with Bayesian methods described for final analyses above, on a combined 12S/COI/CR data set and 13 outgroup taxa. Bayesian methods described above were also used to root with a molecular clock (as in Steele and Storfer, 2006) except that the prior probability distribution on branch lengths was set to a coalescence clock model, which forces a root on the tree. Ingroup rooting with a molecular clock was conducted on the larger CR data set and the two combined data sets.

\section{Results}

\subsection{Identification of major clades and minor groups}

A combined analysis of all data partitions (2226 characters, Table 2) from 22 specimens identifies three major haplotype groups (Fig. 2). Rooting with molecular clock methods identifies the three major groups as clades (but see outgroup rooting below). We refer to the three lineages as Northwest (NW), Eastern (E) and Southwest (SW); the clade names correspond to their respective geographic regions (Fig. 1). The three major clades correspond only in part with their taxonomic identities. The NW major clade corresponds roughly with the species $A$. boreas and includes the type localities for both subspecies, $A$. $b$. boreas (Columbia River and Puget Sound: Baird and Girard, 1852) and A. b. halophilus (Solano Co., CA; Baird and Girard, 1853), which is near San Francisco. The SW major clade includes A. exsul, A. nelsoni and some A. canorus, which are identified from their type localities and are discussed below. The SW clade also includes some divergent lineages in southern California currently considered $A$. $b$. halophilus. The eastern clade (E) is not differentiated taxonomically, but is currently part of $A$. $b$. boreas, and sister to the NW clade.

Due to the more intensive sampling ( $N=117$, Table 2$)$ analyses of $\mathrm{CR}_{882}$ identifies all major clades as well as minor groups (Fig. 3), and refines geographic distributions (Figs. 1 and 4). Rooting with a

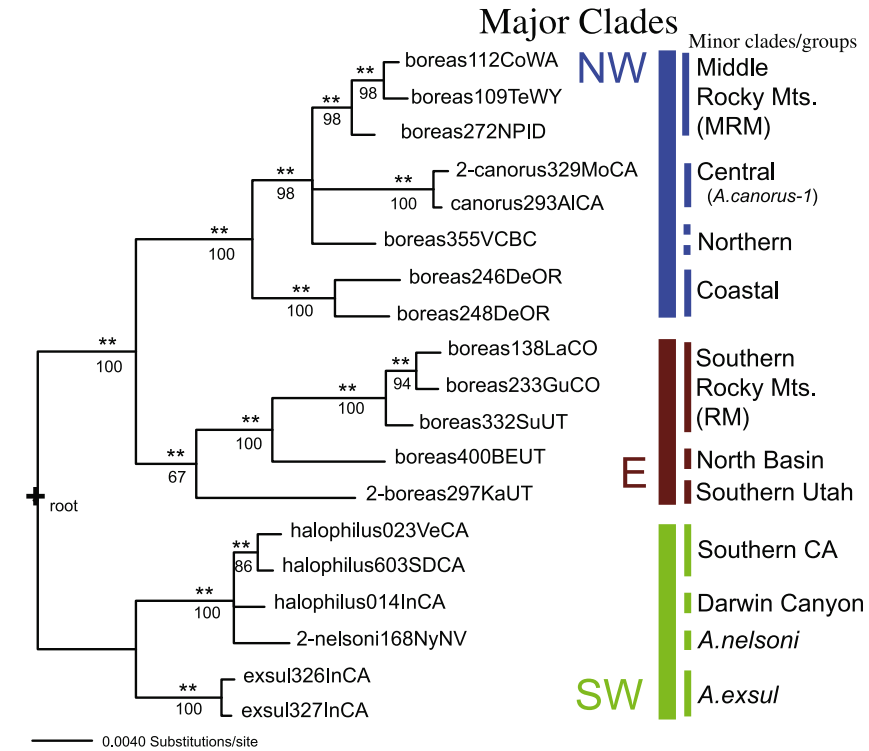

Fig. 2. Major haplotype clades: Bayesian majority rule consensus tree from analyses of 22 samples with all data types combined (2226 aligned sites, Table 2 ). The terminals are identified first by taxon names: boreas (Anaxyrus b. boreas), halophilus ( $A$. b. halophilus), nelsoni (A. nelsoni), exsul (A. exsul) and canorus ( $A$. canorus). The numbers after the species name are unique identification numbers for individual specimens (AMG numbers). Abbreviations for localities (as in Table 1) follow the AMG number. When multiple specimens had identical haplotypes, the number of specimens with that haplotype precedes the species name and all localities for that haplotype are identified. Bayesian posterior probability values are above the branches and are indicted by double asterisks $\left(^{* *}\right)$ for values $97-100$, numeric values are provided for lower support values. Numbers below the branches are bootstrap values above 50 based on $\mathrm{RCI}$-weighted parsimony analyses of the same data set. The major haplotype clades (NW-northwest, SW-southwest, Eeastern) are identified by thick bars to the right of the tree. The minor haplotype clades (identified by thin bars) or assemblages (identified by dotted lines) are identified in greater detail in the analysis of the control region (Fig. 3). The tree shown was based on the HKY + I evolutionary models chosen for each partition and the partitions were unlinked. Additional results (exploratory analyses not shown) including majority rule trees based on clock models and strict consensus trees of RCI-weighted parsimony analyses, did not conflict with, and varied little in support values, to the tree shown. The analysis shown was not rooted, but the position of the root (symbol +) was inferred from an independent analysis using a coalescence clock model.

clock model identifies the major groups as clades, but fails to resolve their sister relationships. Minor groups within the SW major clade (Figs. 3 and 4 ) include a weakly supported $A$. nelsoni (SWnelsoni), a divergent and strongly supported group from nearby Darwin Canyon, Inyo Co, CA (SW-Darwin Canyon), and a strongly supported, but less divergent group of toads from the southernmost distribution of the boreas group in California (SW-SCA). Four genetically divergent but geographically close specimens of $A$. 


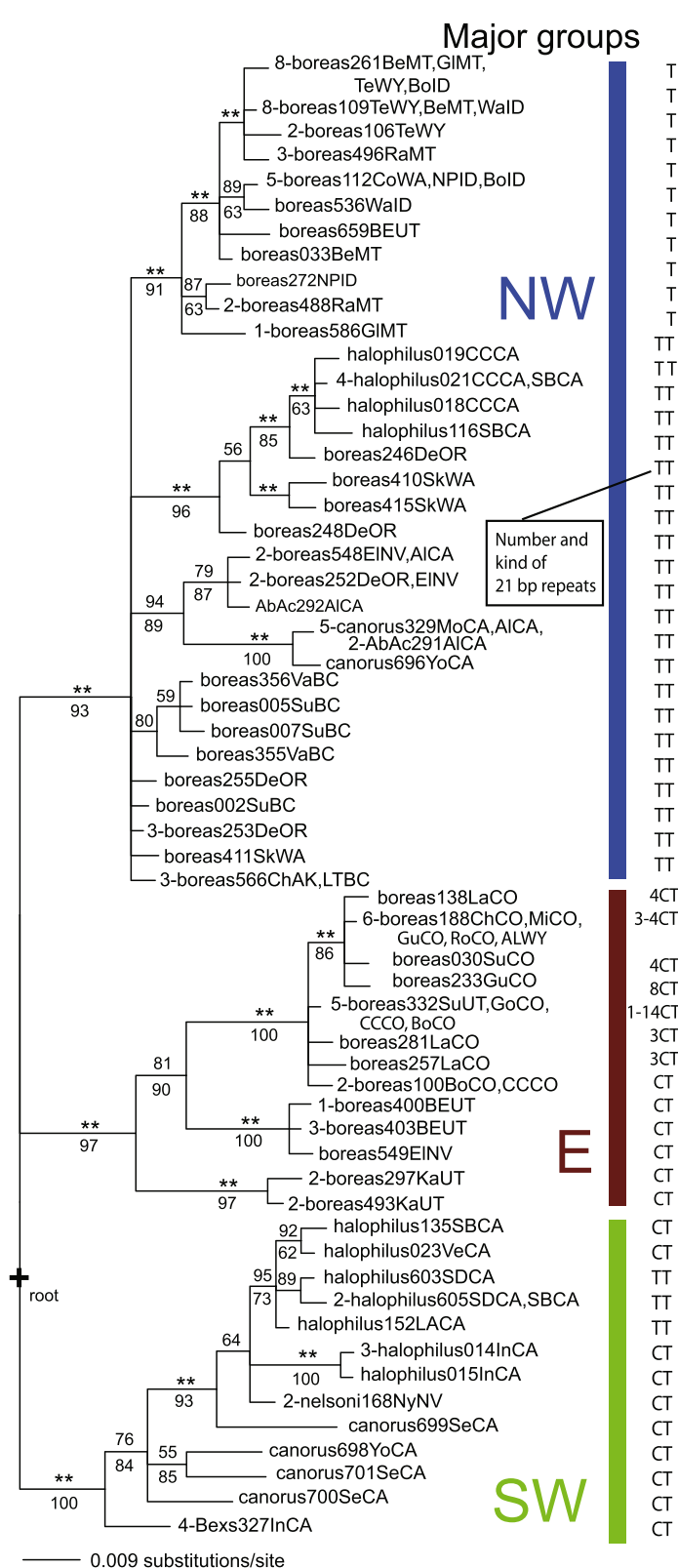

Minor groups

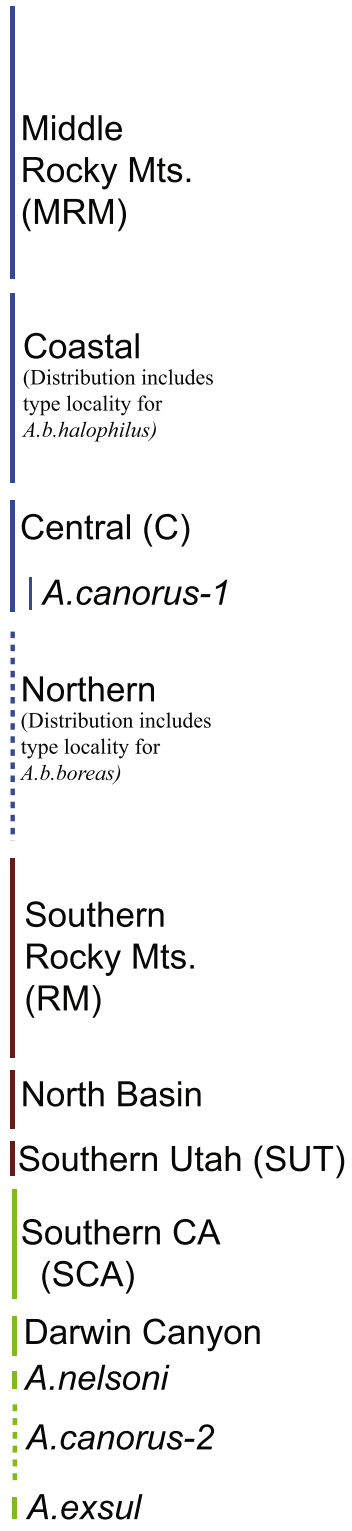

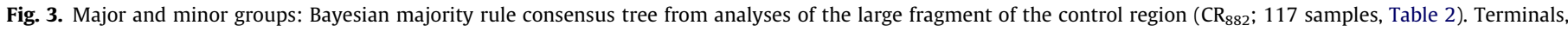

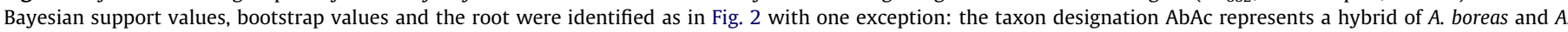

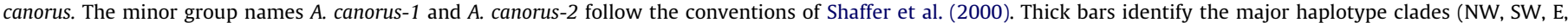

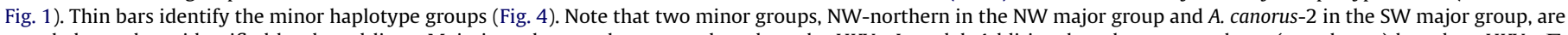

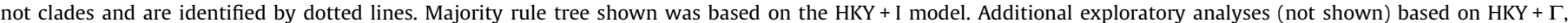

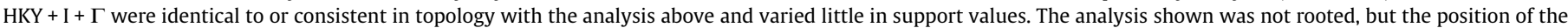

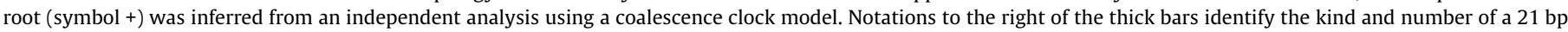

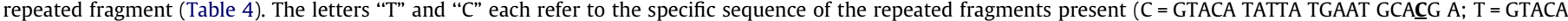

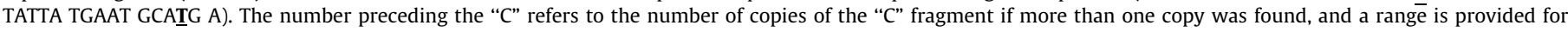
terminals representing haplotypes from multiple specimens that were identical except for the number of repeated copies.

canorus form an additional paraphyletic assemblage within the SW group (called A. canorus- 2 in discussions below). The mtDNA of $A$. canorus was previously found to be paraphyletic or polyphyletic (Graybeal, 1993; Shaffer et al., 2000; Stephens, 2001; Pauly et al., 2004) and analyses here show A. canorus to be paraphyletic and place the two previously recognized and highly divergent groups (A. canorus-1 and A. canorus-2) within the NW and SW major clades, respectively. The last SW minor haplotype group, $A$. exsul, is sister to all other toads in the SW major group. The Eastern (E) major clade consists of three strongly supported haplotype groups (Figs. 3 and 4), including toads at the northern end of the Great
Basin (E-NBasin) at the border of Utah and Nevada, toads in the southern Rocky Mountains of Colorado including the Uinta Mts. of Utah (E-RM), and a third group of toads from southern Utah (E-SUT) that is sister to all other toads in the E major clade.

The NW major haplotype clade covers the largest geographic region and is comprised of three generally less divergent monophyletic groups and one non-monophyletic assemblage. The NWmiddle Rocky Mountain (NW-MRM) group consists of toads from western Washington, Idaho, Montana, and northwestern Wyoming. A second group consists of toads along the western coast (NW-Coastal Fig. 3 and 4) from Washington, Oregon, and into 


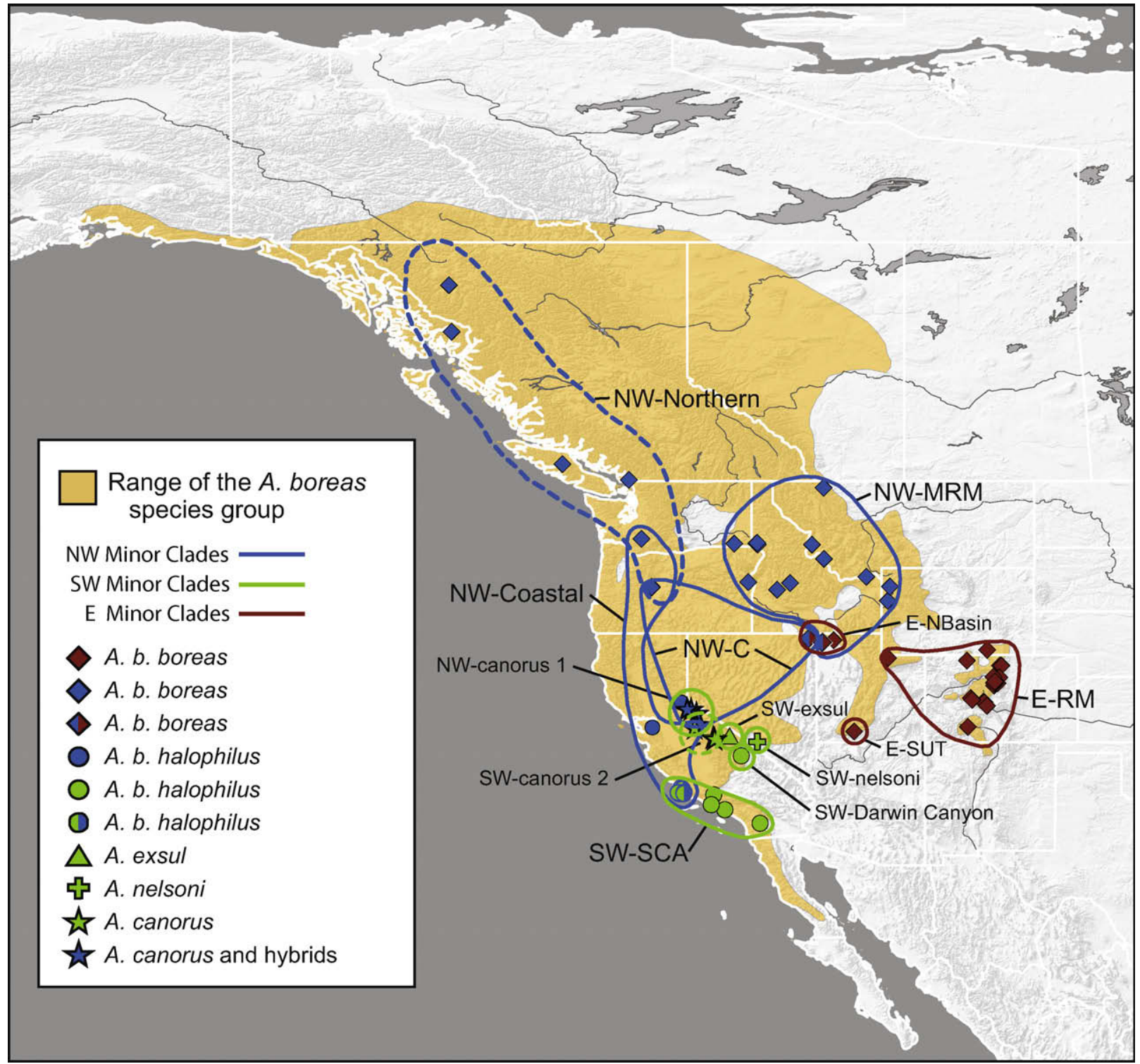

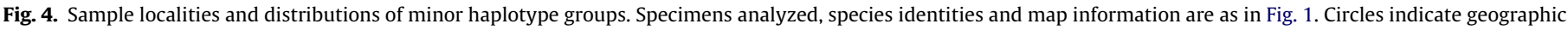

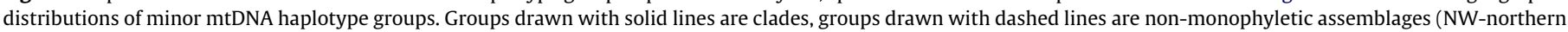
and $A$. canorus-2). Sites with multiple divergent mtDNA lineages are within overlapping circles.

California, as far south as Santa Barbara and east into the Sierra Nevada. This clade includes the type locality of $A$. $b$. halophilus. The $\mathrm{NW}$-coastal clade corresponds to the northern distribution of the subspecies A. b. halophilus (Stebbins, 2003), although it extends further north, into Washington State. A third minor group, $\mathrm{NW}$-central (NW-C), consists of toads from the central region of western US (northeastern Nevada, central Oregon, and the Sierra Nevada of California) and includes toads identified as $A$. boreas as well as $A$. canorus, and known hybrids of $A$. $b$. boreas $\times A$. canorus (within A. canorus-1). All localities sampled from the NW-central clade share haplotypes with other NW clades (Deschutes Co., OR) or other major clades (E in northwest Nevada, SW at the northern end of the Sierra Nevada). A fourth group (NW-northern) is a nonmonophyletic assemblage of toads in the northern coastal regions of North America from Oregon north into Canada and Alaska and the type locality for $A$. $b$. boreas (vicinity of Puget Sound; Schmidt, 1953 ) is found within the distribution of this group. The Bayesian majority rule tree using a coalescent molecular clock (not shown) identified NW-northern as monophyletic but this was not strongly supported (posterior probability $83 \%$ ).

\subsection{Data partitions}

Bayesian analyses of RS, COI and 12S (Fig. 5A-C) although less resolved, are consistent with the major and minor groups discovered with $\mathrm{CR}_{882}$ (Fig. 3) and combinations of partitions (Figs. 2 and 5D) with a single exception. The COI data partition identifies the E group as polyphyletic, with the E-Southern Utah group sister to the NW clade rather sister to the rest of the E clade, although this placement is not strongly supported. Identical results for this placement were obtained in exploratory analyses using all models chosen for the COI partition $(\mathrm{GTR}+\mathrm{I}+\Gamma, \mathrm{GTR}+\mathrm{I}, \mathrm{GTR}+\Gamma$, $\mathrm{HKY}+\mathrm{I}+\Gamma, \mathrm{HKY}+\mathrm{I}, \mathrm{HKY}+\Gamma)$ and placement as sister to the NW clade was supported in some analyses with posterior probability values up to $91 \%$.

$12 \mathrm{~S}$ provided little data (Table 2 ) but results were consistent with other partitions and combinations of partitions. The majority rule consensus tree of $12 \mathrm{~S}$ based on the HKY + I model chosen by the Akaike weights (Fig. 5C) was less resolved than exploratory analyses (not shown) with more complex models using a gamma distribution for across-site rate variation $(\mathrm{HKY}+\mathrm{I}+\Gamma$, one of the 


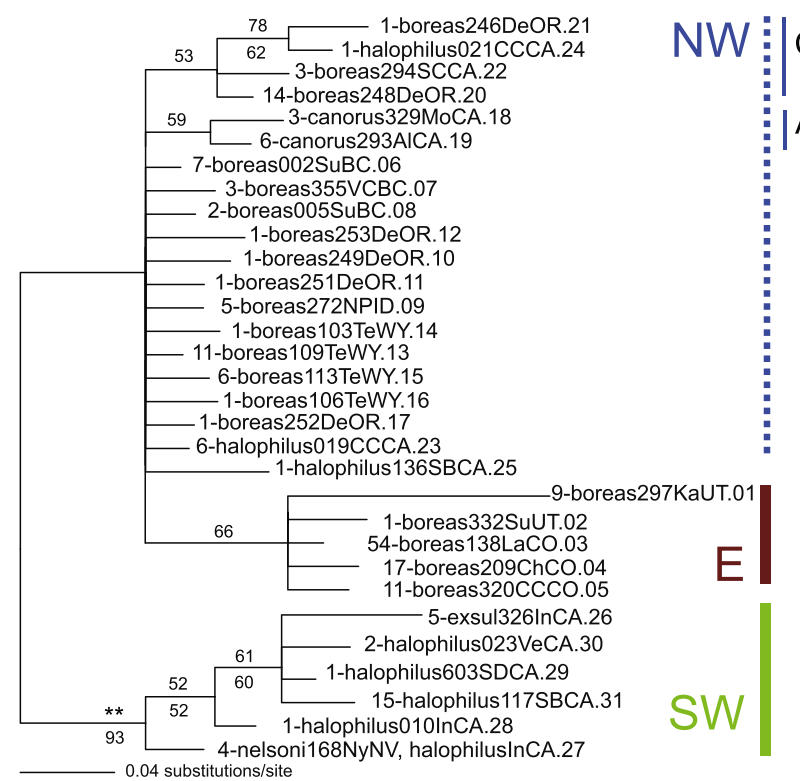

A. Restriction Sites

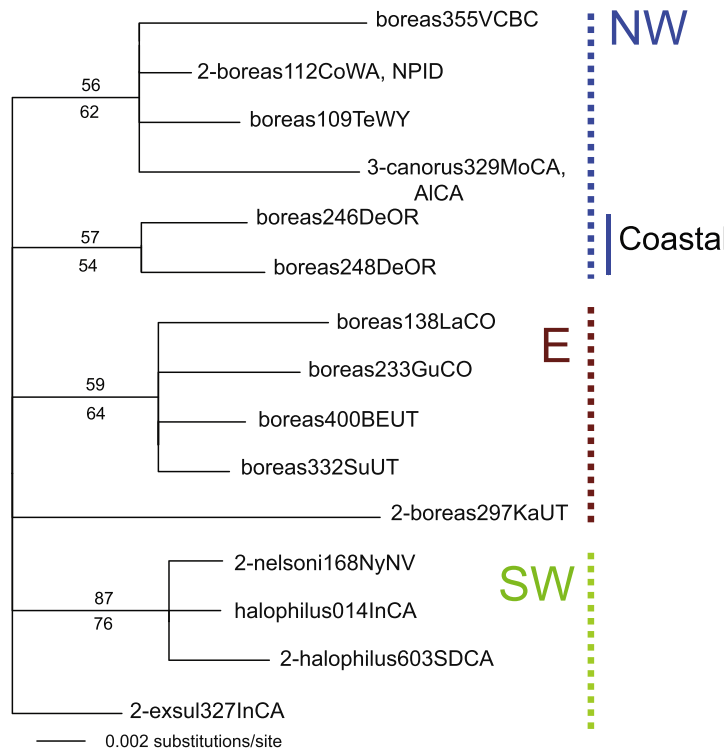

C. $12 \mathrm{~S}$ ribosomal DNA

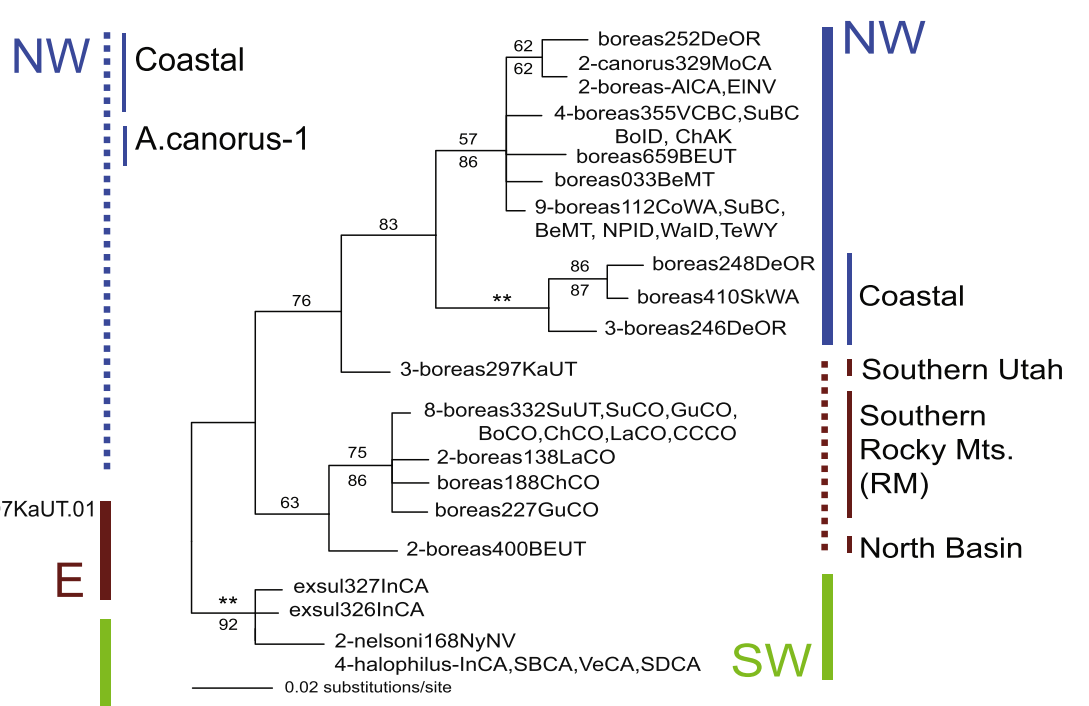

B. Cytochrome oxidase I

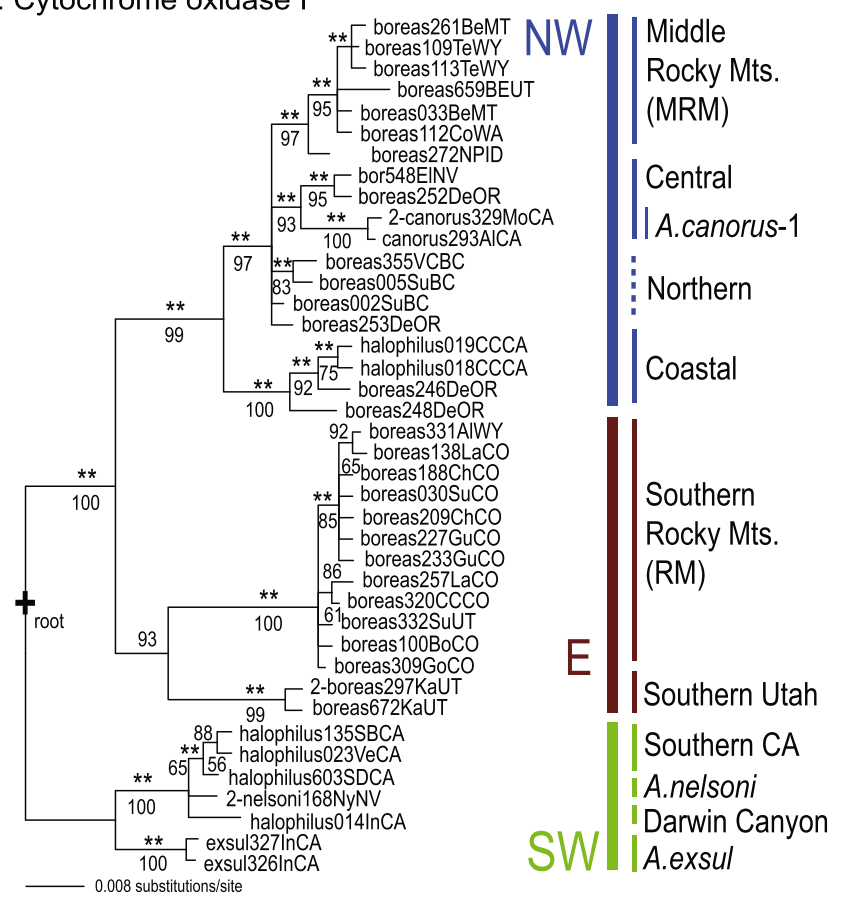

D. Three Partitions (COI, CR882, RS)

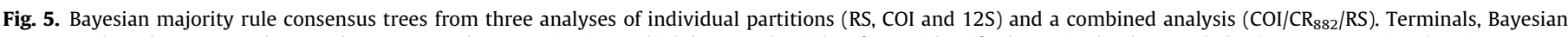

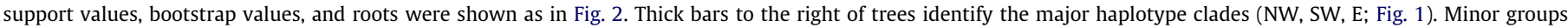

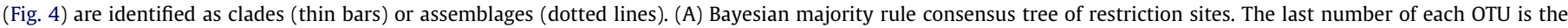

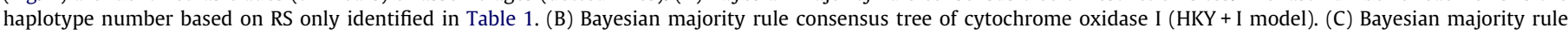

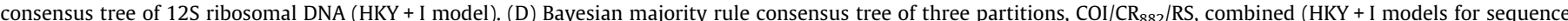

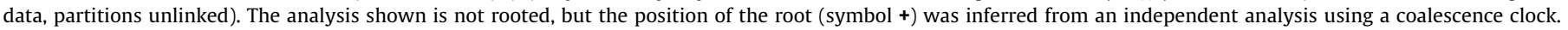

models chosen by hLRT, and GTR $+\mathrm{I}+\Gamma$, used with outgroups), and with analyses using a molecular clock. Although analyses with more complex models identified the major clades E, NW, SW and some minor clades (as found in partition combinations) support was still low, but higher than for less complex models (Lemmon and Moriarity, 2004). The combined analyses of three partitions excluding $12 \mathrm{~S}\left(\mathrm{COI} / \mathrm{CR}_{882} / \mathrm{RS}\right.$, Fig. 5D) identified all major groups and all minor groups for which the larger data set were available (samples from E-north Basin and from A. canorus-2 were missing some data). Thus, in analyses of the boreas group only, excluding the $12 \mathrm{~S}$ (loss of $890 \mathrm{bp}$ ) resulted in the loss of only a few variable and parsimony informative characters (Table 2), but due to the hierarchical sampling strategy, doubled the number of samples that could be analyzed without missing data.
Within $\mathrm{CR}_{882}$, the number of copies and the sequence of a 21-bp repeated region showed a phylogenetic pattern (Fig. 3, Table 4). The repeat varied in number from a single copy to more than 14 copies although the exact number of copies was not identified in samples with large numbers of repeats (greater than 14) due to poor sequence data common in long highly repeated regions. Within the boreas group, the sequence of the repeat varied at site 19 , where specimens had either a "C" or a "T" (Table 4). Some phylogenetic patterns can be seen in both the number and sequence of copies although the patterns were not always fixed among clades (Fig. 3). The sequence of the repeated fragment seems to be relatively conserved; additional variation was found at one site in a single specimen of the boreas group and the homologous fragment could be found in all outgroups (Table 4 ). The number varied with- 
Table 3

Data description and tree information of analyses of 22 samples in the boreas group with all data types

\begin{tabular}{|c|c|c|c|c|c|}
\hline Data partition or combination: & $12 \mathrm{~S}$ & $\mathrm{COI}$ & $\mathrm{CR}_{882}$ & $\mathrm{CR}_{537}$ & RS \\
\hline Length of alignment in base pairs & 890 & 394 & 882 & 537 & 60 sites $^{a}$ \\
\hline Number unique haplotypes & 15 & 13 & 17 & 14 & 14 \\
\hline Efficiency: \% haplotypes per bp & $1.6 \%$ & $3.3 \%$ & $1.9 \%$ & $2.6 \%$ & $3.9 \%$ \\
\hline Number variable characters & 25 & 23 & $\underline{79}$ & 54 & 24 \\
\hline Efficiency: \% of variable characters per bp & $2.8 \%$ & $5.8 \%$ & $\overline{9.0} \%$ & $\underline{10.1 \%}$ & $6.7 \%$ \\
\hline Number parsimony informative characters & 18 & 19 & 64 & $\overline{44}$ & 19 \\
\hline Efficiency: \% PI characters per base pair & $2.0 \%$ & $4.8 \%$ & $\overline{7.2} \%$ & $\underline{8.2 \%}$ & $5.3 \%$ \\
\hline Range of uncorrected $p$-distances (no gaps) & $1.1-0.0$ & $3.0-0.0$ & $4.5-0.0$ & $\overline{6.0-0.0}$ & - \\
\hline Length of most parsimonious tree & 29 & 29 & 104 & 73 & 30 \\
\hline
\end{tabular}

Numbers discussed in the text are in bold and underlined.

a The 60 restriction sites represent 360 base pairs.

in the boreas group, but high numbers of copies were found only in the " $C$ " copy and in the E-southern Rocky Mountains, except for one specimen from Contra Costa Co., CA, that had eight or more copies of "T". Only a single copy was found in outgroups. Although neither the number of copies nor the sequence variation were included in the analyses of the whole group, both seem to show some phylogenetic information that might be useful in examining regional variation.

The utility of partitions varied in a comparison of 22 samples with all data (Table 3). The shortest fragments (RS and COI) were the most efficient in identifying the largest number of unique haplotypes per base pair of sequence obtained (3.9\% and 3.3\% respectively). The larger $\mathrm{CR}_{882}$ fragment identified the greatest total number of variable (79) and parsimony informative characters (64), but the smaller $\mathrm{CR}_{537}$ fragment was the most efficient in identifying the greatest proportion of variable $(10.1 \%)$ and parsimony informative characters (8.2\%) per length of sequence obtained. Comparing only three efficiency parameters (\% haplotypes/bp, variable characters/bp, and parsimony informative characters/bp), $\mathrm{CR}_{537}$ was the most efficient in identifying variable and parsimony informative characters per length of sequence obtained. Analyses of $\mathrm{CR}_{537}$ (not shown) included only $61 \%$ of the larger $\mathrm{CR}_{882}$ fragment. This resulted in the loss of 14 unique mtDNA haplotypes, however, all relationships were identical to analyses with $C_{882}$ data and all major and all but one minor group was resolved (some haplotypes from the southern California were identical to A. nelsoni haplotypes).

\subsection{Rooting}

Bayesian analysis conducted with a coalescence clock identifies the SW group as sister to a NW/E clade (Figs. 2, 3 and 5D). Bayesian analyses with outgroups (Fig. 6) strongly supports the monophyly of the boreas species group, the monophyly of both the $\mathrm{E}$ and NW major clades, and the monophyly of a combined E/NW clade. However, the majority rule tree identifies the SW group as paraphyletic, and A. exsul as sister to the NW/E clade. This root placement is not strongly supported, but suggests that at least portions of the SW, if not the entire SW, may be ancestral in the species complex. With the exception of root placement, all relationships within the boreas species group identified from analyses with outgroups, are consistent with analysis of ingroups only. Strongly supported relationships among the taxa used as outgroups were consistent with strongly supported results from previous analyses of mitochondrial genes (Frost et al., 2006a; Pauly et al., 2004; Graybeal, 1997; Pramuk et al., 2001; Pramuk, 2006). In exploratory analyses the root position was affected by outgroups chosen; rooting with single species within the Nearctic clade resulted in various weakly supported placements of the root (analyses not shown). However, rooting with multiple divergent species in the Nearctic clade, rooting with species in the Ollotis or Chaunus genera, or a combination of Nearctic and Ollotis/Chaunus always resulted in a root placement between $A$. exsul and the rest of SW.

\section{Discussion}

\subsection{Discovered mtDNA Clades}

The phylogenetic pattern of mtDNA indicates that the species $A$. boreas, as recognized by Stebbins (2003), is not monophyletic (Figs. 2, 3 and 5D). Anaxyrus boreas is either paraphyletic, with multiple localized species (A. exsul, A. nelsoni, A. canorus and perhaps other undescribed taxa) derived from within $A$. boreas, or $A$. boreas is polyphyletic and comprises only portions of three major mtDNA clades, NW, SW and E (Fig. 3). The subspecies $A$. $b$. boreas occurs in both the NW and E major clades, and A. b. halophilus, in the SW and NW. We suggest that $A$. boreas comprises a widespread clade corresponding only to the NW major clade whose distribution includes the type locality (mouth of the Columbia River, Baird and Girard, 1852). Although taxon rank (species or subspecific evolutionary units) is not clear based solely on mtDNA, the NW haplotype groups and assemblages comprise a set of monophyletic units. Anaxyrus boreas boreas is best represented by the NW-northern assemblage, because the type locality occurs within its distribution (vicinity of Puget Sound; Baird and Girard, 1852). Anaxyrus boreas halophilus is best represented by NW-coastal, because this mtDNA haplotype is the only one that occurs in the vicinity of the type (Benicia, Solano Co., CA; Baird and Girard, 1853). The distribution of the mitochondrial NW-coastal clade and A. b. halophilus (Stebbins, 2003) differ somewhat at the northern and southern edges: the NW-coastal clade occurs a little farther north (into Washington State), but not as far south as the previously described A. b. halophilus (NW-coastal occurs only down to Santa Barbara, CA). Although we included few samples from central California, the sole distribution of the NW-Coastal haplotype in this region is supported by more extensive sampling by Stephens (2001), who identified the "central CA boreas" clade with a similar distribution to our NWCoastal clade, and a similar relationship to the northern A. canorus and $A$. boreas. Our results are also consistent with the geographic distributions of clades/groups of Graybeal (1993) and Feder (1973), who examined mitochondrial cytochrome b sequences and allozymes, respectively. Careful morphological studies of the whole group, especially of the type specimens, are clearly needed in light of the mtDNA evidence because genetic analyses have previously identified unrecognized morphological differentiation (e.g., Shaffer et al., 2004; Vredenburg et al., 2007). More extensive analyses of nuclear data (e.g., genes examined in Feder, 1973; Maxson et al., 1981; Graybeal, 1997; Simandle, 2006; Pramuk, 2006; Frost et al., 2006a) and finer sampling would be valuable to determine taxonomic status. 


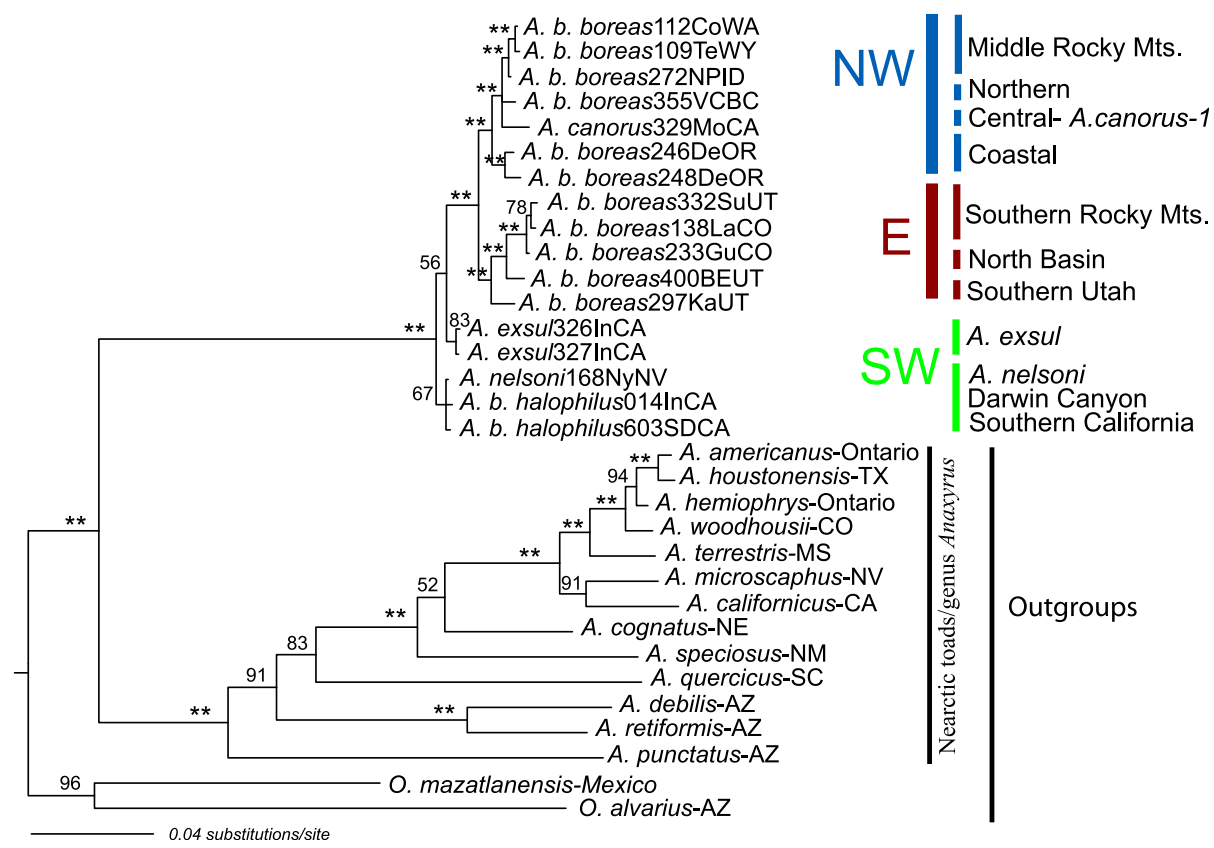

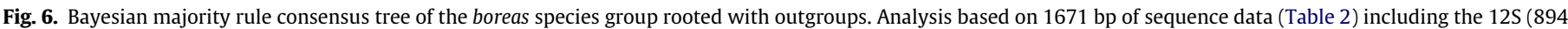

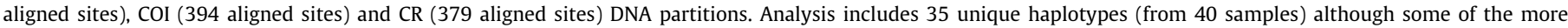

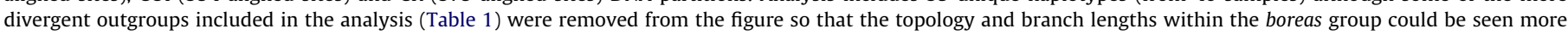

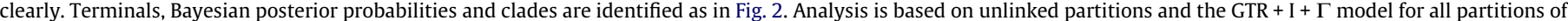
the data.

Table 4

Sequence alignment of a $21 \mathrm{bp}$ repeated region

\begin{tabular}{|c|c|c|c|}
\hline Species groups & Number samples & Sequence of all 5' copies variable site: 19 & Sequence of final $3^{\prime}$ copy variable sites: 17,19 \\
\hline \multicolumn{4}{|l|}{ boreas species group: } \\
\hline $\mathrm{E}-($ all $), \mathrm{SW}(n=16)$ & 35 & GTA CAT ATT ATG AAT GCA $\underline{\mathbf{C} G A}$ & GTA CAT ATT ATG AAT GCA $\underline{\text { TGA }}$ \\
\hline $\mathrm{NW}(n=38), \operatorname{SW}(n=4)$ & 42 & GTA CAT ATT ATG AAT GCA $\underline{\text { TGA }}$ & GTA CAT ATT ATG AAT GCA TGA \\
\hline NW-MRM & 29 & & GTA CAT ATT ATG AAT GCA $\underline{\text { TGA }}$ \\
\hline $\begin{array}{l}\text { Unique sequence: } \\
\text { NW-MRM (AMG586) }\end{array}$ & 1 & GTA CAT ATT ATG AAT GCA $\underline{\text { TGA }}$ & GTA CAT ATT ATG AAT GIA $\underline{\text { TGA }}$ \\
\hline \multicolumn{4}{|l|}{ Outgroups: } \\
\hline americanus species group & 5 & & GTA CAT ATT ATT AAT GIA TWA \\
\hline A. microscaphus & 1 & & GTA CAT ATT AT $\underline{T}$ AAT G $\underline{\mathbf{T}}$ A $\underline{\mathbf{T}} \underline{\mathbf{S}}$ \\
\hline A. punctatus & 1 & & GTA CAT ATT ATI AAT GCA $\underline{\mathbf{T}}$ AG \\
\hline O. mazatlanensis, 0 . alvarius & 2 & & GTA CAT ATT ATG YAT GCA $\underline{\text { TGA }}$ \\
\hline C. marinus & 2 & & GTA CAT ATT ATG YAT GCA $\underline{\mathbf{C}}$ GA \\
\hline
\end{tabular}

The number of copies and the sequence of the repeat fragment varied within and among major groups (Fig. 3 ).

When sequence variation was found in outgroups the variation was identified with standard abbreviations: $\mathrm{W}=\mathrm{A} / \mathrm{T}, \mathrm{V}=\mathrm{A} / \mathrm{C} / \mathrm{G}, \mathrm{S}=\mathrm{C} / \mathrm{G}, \mathrm{Y}=\mathrm{C} / \mathrm{T}$.

We suggest the SW major clade corresponds to a suite of new and previously described species or assemblages (Figs. 3 and 4). These include $A$. exsul, $A$. nelsoni, several lineages from southern CA including Darwin Canyon (currently regarded as A. b. halophilus) and the assemblage A. canorus-2 (discussed below). Anaxyrus exsul occurs in only four isolated desert springs in the Deep Springs Valley, between the Inyo and White Mountains of California (Fellers, 2005; Simandle, 2006), the type locality. The small population size and relatively long time of geographic isolation (Hubbs and Miller, 1948) are consistent with the monophyly and high divergence found in mtDNA here. Anaxyrus nelsoni is currently known only from several desert springs and the Amargosa River within the Oasis Valley, NV (Altig and Dodd, 1987; Goebel et al., 2005; Simandle, 2006) and specimens for analyses here were collected from the type locality at Crystal Springs. The mtDNA of two A. nelsoni were sister, but were not highly differentiated from mtDNAs in southern California. This lack of divergence suggests a close relationship to previously unrecognized lineages of the SW clade. A broad distribution of close relatives is further supported both by allozyme data (Feder, 1973), which identified populations in Owens Valley and Darwin Canyon that shared alleles (in low frequency) with A. nelsoni and $A$. exsul and by the wider distribution of $A$. nelsoni, suggested in early studies (Stejneger, 1893; Linsdale, 1940; Wright and Wright, 1949; Karlstrom, 1962). In contrast, results from Pauly et al. (2004) suggest that some A. nelsoni mtDNA haplotypes are nested within our NW group (one specimen of $A$. nelsoni was more closely related to $A$. boreas of Alaska and A. canorus-1, than to A. exsul and toads from southern CA). It is possible that like $A$. canorus, mtDNAs of $A$. nelsoni may contain haplotypes of both the NW and SW mtDNA major clades. The clade, SW-Darwin Canyon, has a divergent haplotype but is not recognized taxonomically. The minor clade with the largest distribution, SW-southern CA is found only in southern California. This clade is consistent with the "southern boreas" clade of Stephens (2001) in its distribution and 
relationship to the southern A. canorus. Similarly, Graybeal (1993) found $A$. boreas from San Diego to be sister to the southern $A$. canorus, and both were closely related to $A$. exsul.

The eastern mtDNA clade comprises three divergent groups. Southern Utah (E-SUT), is a disjunct population discovered in 1994 (Ross et al., 1995). The group E-north Basin is similarly divergent, but haplotypes from the NW-central and NW-middle Rocky Mountains also occur in the region. The E-Rocky Mountain clade was discovered largely from the geographically disjunct region in Colorado and southeastern Wyoming (the Southern Rocky Mountain Population, SRMP), but a single haplotype from this clade was also discovered in the Uinta Mts. of Utah. The SRMP, listed as endangered in Colorado, is disjunct from all other toads (Fig. 1): the Red Desert and dry plains in southwest and central Wyoming serve as effective barriers between toads in northwest Wyoming and southeast Wyoming, and toads in Colorado are separated from those in Utah by at least $200 \mathrm{~km}$ and the dry intermountain basin of the Green River. The complete geographic isolation of the toads in the SRMP suggest that the closely related haplotype in the Uinta Mountains, Utah, is due to incomplete lineage sorting, commonly found in recently isolated groups.

Previous studies (Graybeal, 1993; Shaffer et al., 2000; Stephens, 2001; Pauly et al., 2004), found A. canorus to be polyphyletic or paraphyletic with $A$. canorus- 2 . The regional studies by Graybeal (1993) and Shaffer et al. (2000) identified A. exsul as a sister taxon to the southern lineage, $A$. canorus-2, corroborating a placement within the SW major clade. Data presented here identifies A. canorus-2 as a paraphyletic assemblage, as was found by Stephens (2001). Anaxyrus canorus-1 was found in this study to be within the widely distributed NW major clade (monophyletic with toads from northern and central CA as well as southern OR) and this is also consistent with Stephens (2001). The derivation of $A$. canorus from within $A$. $b$. boreas was suggested by both Stebbins (1951) and Karlstrom (1962) based on morphological similarities, and this is consistent with finding the A. canorus-1 lineage within the NW major clade. At this point $A$. canorus appears to be either multiple entities or derived from multiple divergent mtDNA lineages.

Results here are remarkably consistent with the very first molecular phylogeographic analysis of the group (Feder, 1973) based on allozyme data. UPGMA dendrograms, based on distances between populations, showed $A$. exsul to be most genetically similar to $A$. nelsoni, and an A. exsul/A. nelsoni group to be most similar to a A. b. boreas/A. b. halophilus group. Feder examined A. $b$. boreas only from Washington near the type locality (our NW-Northern group), and her $A$. $b$. halophilus were collected from within the distribution of our NW-Coastal clade; thus her results from nuclear DNA are similar to those found with mtDNA. Feder did not sample A. boreas from southern California (SW-CA clade) so it is still unclear whether nuclear DNA will identify a SW-southern California clade found with mtDNA. In contrast to our study, Feder found $A$. canorus to be sister to all other specimens in the group. This finding may reflect the difficulty of rooting a group of close taxa with distant outgroups, or is a result due to sampling a paraphyletic $A$. canorus from both the SW and NW lineages.

\subsection{Sympatry, hybridization and introgression among mtDNA lineages}

Introgression of mtDNA is of concern because it precludes accurate identification of organismic lineages with mtDNA analyses. Hybridization is of special concern among toads because both close and divergent species interbreed where they are sympatric (or in captivity; Blair, 1972a), and F1 specimens develop. This unusual level of hybridization in toads may occur because of external fertilization and the "trial and error" method of mate recognition by males in this species group (Karlstrom, 1962). Within the boreas group, A. boreas hybridizes with A. hemiophrys in Alberta (Stebbins,
2003), with A. microscaphus in southwestern Utah (Blair, 1955), and with $A$. punctatus in California, despite differences in habitat preferences, species-specific male mating calls, and different timing of reproduction among species (Feder, 1979). In addition, hybridization among lineages of divergent species may not always be identified by morphology (Lamb and Avise, 1987); some F1 hybrid individuals between $A$. boreas and $A$. punctatus were not recognized without genetic data (Feder, 1979). If hybrids from taxa that are highly morphologically divergent cannot be identified in the F1, surely hybrids among morphologically similar lineages go unnoticed. However, the occurrence of hybrids is not always associated with introgression and does not always imply conspecificity (i.e., lack of speciation, Mebert, 2008; Nosil, 2008). All hybrids identified in this study (from morphology) were among closely related lineages and limited to the NW-central minor group. Hybrids of $A$. boreas and $A$. canorus were identified by collectors at the northern end of the range of $A$. canorus (Figs. 2 and 4). Hybridization studies produced F2 hybrids of $A$. canorus and $A$. boreas in the laboratory (Blair, 1972c), but the collection localities of these specimens were not identified by Blair so their correlation with mtDNA studies is not clear. Hybridization between $A$. b. boreas and $A$. $b$. halophilus in northern California was mentioned, but not described in any detail by Camp (1917a) and Storer (1925), but the large range of sympatry was identified with morphological intermediates (Stebbins, 1951). It is not likely that specific levels of mtDNA divergence indicate reproductive isolation (Hillis, 1988). However, genetic distances (uncorrected p-differences) among $A$. americanus, and $A$. hemiophrys, used as outgroups here, had lower levels of mtDNA divergence than those found among the major clades in the boreas group yet they are maintained by hybrid zones (Green, 1983) with limited introgression (Green and Pustowka, 1997). Yet regions of sympatry are of special concern because introgression is possible, but not necessarily occurring, where the toads have the opportunity to interbreed. Analyses of nuclear genes that assort independently are critical in these regions.

\subsection{Value of partitions}

Due to the increased ease of sequencing, RS of the whole mtDNA are rarely used today in phylogenetic analyses and were thought to have a limited lifespan even when they were first collected (Felsenstein, 1992). But RS here provided two surprises. First, RS were most efficient at identifying the largest number of haplotypes per bp examined (Table 3 ), a characteristic that is very useful in identifying large numbers of individuals and in looking at very fine relationships (Avise et al., 1998; Waldman et al., 1992). A second surprise was the emergence of phylogenetic signal consistent with other sequence data, when RS were analyzed with Bayesian methods (Fig. 5A). Similar topologies among Bayesian analyses of data partitions suggest that RS data contain usable phylogenetic signal and, if available from past analyses, could be combined with sequence data rather than discarded. Similarly, $12 \mathrm{~S}$ was one of the first DNA regions for which primers were developed (Palumbi et al., 1991) and was used commonly for vertebrate systematics. Despite the limited variability among close lineages (Tables 2 and 3), the gene can provide a tree topology consistent with larger data sets (Figs. 2 and 5C) especially with analyses using more complex models of evolution.

The control region provided a higher number of variable characters than ribosomal and protein-coding genes (Tables 2 and 3 ) as was found in previous studies (Liu et al., 2000; Fu et al., 2005). However, in some species the $5^{\prime}$ end of $\mathrm{CR}_{882}$ contains inserts or repeated regions that make amplification, sequencing, or alignment difficult (Goebel et al., 1999; Liu et al., 2000; Smith and Green, 2004; Stöck et al., 2006; this study) and was excluded in analyses 
with outgroups in this study due to both the inability to amplify the fragment in some species and difficulty in aligning taxa from multiple divergent species groups. The smaller $\mathrm{CR}_{537}$ fragment, which excludes the $5^{\prime}$ end of the longer $\mathrm{CR}_{882}$, still provided the greatest number of variable and parsimony informative characters per bp examined (Table 3) with only slightly less resolution than the longer $\mathrm{CR}_{882}$ fragment. $\mathrm{COI}$ has been proposed as a gene useful in barcoding (Herbert et al., 2003; Herbert and Gregory, 2005), which is a process to provide a unique genetic identity for divergent lineages. In this group COI identified divergent lineages (Fig. 5B), even this small fragment (394 bp) would function as a barcode. Although barcoding has many limitations (Meier et al., 2006), $\mathrm{CR}_{882}$ or $\mathrm{CR}_{537}$ might be useful among bufonids to assist in this process.

\subsection{Rooting and estimating time of divergence}

Lack of a definite root is not uncommon in intraspecific phylogenetic analyses due to the high similarity of haplotypes within species or species groups and the often distant outgroup haplotypes (Castelloe and Templeton, 1994; Wood et al., 2008). In this study, rooting methods with a molecular clock provided consistent results (SW was sister to a NW/E clade in analyses with larger combined data sets), whereas rooting with outgroups suggested the root was within the SW group. Absence of a clearly inferred root precludes identification of monophyletic groups, because monophyly depends on root position. However, all lines of evidence suggest that the E and NW groups are monophyletic and that the SW group is either sister to the $\mathrm{E} / \mathrm{NW}$ clade, or sister to that clade plus A. exsul.

Estimates of divergence times can be made from mtDNA sequence similarities if a relatively constant rate of molecular evolution is assumed (e.g., Shaffer and McKnight, 1996; Macey et al., 1998; Masta et al., 2003). We estimated times of divergence from a rate of $1.644 \%$ bp changes per lineage, per million years as estimated by Stöck et al. (2006) for control region sequences in Bufo virdis. We recognize that our estimate is limited because $B$. virdis is quite distant from $A$. boreas (Frost et al., 2006a) and estimated rates change both among lineages and with the depth of evolution. In addition, dates based on single mtDNA genes (compared to 5-10 nuclear genes) have a high variance (Carstens and Knowles, 2007) and the rate of $1.644 \%$ did not include an estimate of error. In the boreas group, the largest uncorrected pair-wise sequence divergences of $\mathrm{CR}_{882}$, varied between major lineages (E-SW: 2.8464.684\%, E-NW: 2.163-4.299\%, S-NW: 2.278-4.303\%) about twice as much as within major lineages (E: 0.0-2.253\%, SW: $0.0-$ 2.088\%, NW: 0.0-2.507). Estimated from rate of 1.644\%, the mtDNA of the major groups began diverging at least 1.425-0.658 Mya, and mtDNA began diverging within major groups at least $0.762-$ 0.685 Mya (NW-0.762, SW-0.635, E-0.685 Mya). In general, the divergence of mtDNA predates isolation of populations into species (Arbogast et al., 2002). Acknowledging the substantial variance that might be associated with these estimates, it is reasonable to assume that the major clades began diverging from each other as long ago as the early to mid-Pleistocene, and minor groups began diverging after that. This is consistent previous hypotheses of Pleistocene divergence within the group (Myers, 1942; Karlstrom, 1958 and 1962; Blair, 1972c; Maxson et al., 1981).

\subsection{MtDNA phylogeography and biogeographic history}

Pleistocene glaciation has long been thought to affect the evolutionary history of species in western North American (Avise et al., 1998; Pielou, 1991; Hewitt, 1996, 2000), leaving two specific phylogeographic patterns in multiple species. First, low diversity in many species of the northern regions of North America are often explained by range expansions following retreating glaciers (e.g., Highton and Webster, 1976; Zink, 1996 (birds), Green et al., 1996; Hovingh, 1997; Lee-Yaw et al., 2008 (amphibians), Soltis et al., 1997(plants); Conroy and Cook, 2000 (rodent)). This pattern is best seen in the NW-northern group (Fig. 4) because the control regions of toads in Alaska were quite similar to those in Washington State (Fig. 3). The NW-Middle Rocky Mountain Group also has less genetic diversity compared to the E clade although the geographic distributions sampled here were similar in size. Second, refugia from Pleistocene glaciations resulted in shared phylogeographic distributions of species. The Klamath-Siskiyou Mountains, near the border of Oregon and California, remained unglaciated throughout the Pleistocene and still contain high biological diversity and endemism (e.g., Wake, 1997; Wilke and Duncan, 2004 (Slug); Mead et al., 2005; Steele and Storfer, 2006). This region could have served as a refugium for boreal toads in the NW group, and allowed the divergence of the NW-coastal minor group from the more northern NW-northern assemblage (Fig. 4). Other refugia in the Pacific Northwest have been proposed (e.g., Columbia River, McCusker et al., 2000 (fish); Miller et al., 2005; Wagner et al., 2005) and these too may have resulted in distinct northern and southern lineages of multiple species of plants, salamanders and newts (Soltis et al., 1997; Brunsfield et al., 2001; Steele and Storfer, 2006; Kuchta and Tan, 2005) and the distinct minor groups seen in A. boreas. A similar pattern of species with northern and southern populations is seen in the Sierra Nevada in frogs (Macey et al., 2001), salamanders (Moritz et al., 1992; Tan and Wake, 1995), and snakes (Rodrgíuez-Robles et al., 1999) as well as A. canorus (Shaffer et al., 2000; Stephens, 2001) which occurs in both the NW and SW clades. Explanations for other patterns of divergence are less clear. Divergence among minor groups further from the coast (between the NW-northern and NW-middle Rocky Mountains) echoes variation found in diverse organisms, including amphibians, mammals and trees (Carstens et al., 2005a,b). However, the vicariance between western and inland populations of tailed frogs (Ascaphus; Nielson et al., 2001, 2006), giant salamanders (Dicamptodon; Daugherty et al., 1983), and lungless salamanders (Plethodon; Howard et al., 1993) resulted from drying of the Columbia Plateau after the rise of the Cascade Mountains during the Pliocene. These amphibians are all associated with streams or seeps in forest habitats and inland and western species are distinctly allopatric. Anaxyrus boreas occupies a wider range of habitats, and is currently distributed across the Columbia Plateau between the middle Rocky Mountains and Cascades (Nussbaum et al., 1983). It is more likely that the phylogeography of $A$. boreas in this region more resembles that of voles (Microtus richardsoni) and willow (Salix melanopsis), which show evidence of post-Pleistocene dispersal (Carstens et al., 2005a).

Species that were highly water-dependent were also impacted heavily by the complex pluvial cycles in the Great Basin, that may have resulted in multiple range contractions and expansions (Mifflin and Wheat, 1979; Stokes, 1986; Green et al., 1996; Hovingh, 1997; Hewitt, 1996 and 2000; Masta et al., 2003). Present distributions of salamanders (Ambystoma tigrinum) and anurans (Lithobates pipiens, Rana luteiventris, Anaxyrus woodhousii, A. punctatus and $A$. boreas) are all consistent with fragmentation of populations in the Pliocene and Pleistocene within the Great Basin region. Flooding over large regions from glacial melting could have allowed great dispersal distances perhaps explaining nearly identical haplotypes of the NW-central group, found in northern California, north eastern Nevada and central Oregon. Wet periods may have allowed toads to enter regions that are now geographically isolated by dry deserts, such as eastern California (A. exsul), Nevada ( $A$. nelsoni), and the Southern Rocky Mountains in Colorado (SRMP). Subsequent isolation may have allowed populations to diverge. The complexity of the divergence pattern may depend heavily on 
factors that are difficult to ascertain now, such as the number of pluvial cycles, population sizes, and whether ancestral haplotypes were retained or lost (e.g., Masta et al., 2003).

\subsection{Conservation implications}

A rearrangement of the taxonomy of the boreas species group would profoundly influence the conservation of several species and lineages, some of which have undergone recent declines (Hammerson, 1999; Corn, 2003; Davidson and Fellers, 2005; Muths and Nanjappa, 2005), or exist in small numbers of isolated, vulnerable populations (Stephens, 2001; Fellers, 2005; Goebel et al., 2005; Simandle, 2006). Anaxyrus canorus is a current candidate for Federal listing (US Fish and Wildlife Service, 2002), but is paraphyletic, split between the NW and SW haplotype groups. Different taxonomic outcomes from additional research are possible (recognition as two distinct species or, conversely, combination with other minor groups). These two possibilities would have significant but likely opposite effects on decisions to list populations as threatened or endangered. Populations of $A$. $b$. boreas in southern Wyoming, Colorado and northern New Mexico (SRMP) were removed from the US Federal candidate species list, because their loss would not significantly affect the distribution of $A$. $b$. boreas, and they were not genetically distinct from populations in Utah (Thompson, 2005). Recognition of the eastern major group as one or more distinct species could result in reconsideration of that decision. The boreas species group has many highly divergent and isolated lineages at the southern edge of its distribution and especially surrounding the Great Basin region (similar to the Rana luteiventris, Bos and Sites, 2001). Recognizing this phylogeographic pattern may encourage wildlife agencies to proceed with caution when managing and protecting toads and/or other amphibians in and surrounding the Great Basin, as they may be composed of many cryptic lineages.

Although we are cautious about delimiting species here, we, like Wood et al. (2008), believe some, if not many divergent mtDNA lineages are species, and provide a better reflection of species diversity than the current taxonomy. Several previous names exist that might be appropriate for phylogeographic groups. Provo, UT is the type locality of $A$. pictus (Cope, 1875) which was later determined to be $A$. boreas (Cope, 1889). This name may be appropriate for clades in the eastern portion of the region, depending on their taxonomic status. Specimens from Provo were not examined here, and both the E-N Basin and E-Rocky Mountain haplotype clades occur close by. The La Brea Tar Pits (Camp, 1917b) are the type locality for $A$. nestor (currently a synonym of $A$. $b$. halophilus, Tihen, 1962). This name may be appropriate for potential species within the SW clade, and falls within the distribution of the SW-southern California haplotype clade.

\section{Acknowledgments}

We thank Alisa Gallant for preparing the maps and Tom Beatty for assistance in drawing the phylogenetic trees. Hobart Smith, Gregory B. Pauly, Deidre Evans, and Brian Bovard provided valuable comments on the manuscript, and Juliana Feder provided helpful discussions early on. We thank the following people for assistance collecting specimens or providing tissue: M.J. Adams, Andy Blaustein, S. Burton, Craig Fetkavich, Frances Cassirer, Cindy Carey, Rick Fridell, Erik Gergus, David Green, John Goettl, David Goode, Karin Hoff, Greg Horstman, Peter Hovingh, Richard Holland, W. Bryan Jennings, Mike Jennings, Mark Jones, Lauren Livo, Chuck Loeffler, David Martin, S.K. Meegan, Duane Monk, Keith Pahlke, Charles Peterson, R.V. Polermo, Bruce Rosenlund, David Ross, Jan Roth, H.B. Shaffer, R.L. Seib, Hobart Smith, Sam Sweet, Louise Trippe, Heather Way, Ed Wessman and the Utah Division of Wildlife. Specimens were made available from the following museum collections: $\mathrm{Mu}$ seum of Vertebrate Zoology, University of California, Berkeley (Anna Graybeal and Eric Johnson), Royal Ontario Museum (Ross McCollough). Todd Bergren, Biology Department, Community College of Aurora, Aurora, CO, allowed AMG to use the genome analyzer. Funding was provided by the National Biological Service (Midcontinent Ecological Science Center, Ft. Collins, CO), University of Colorado Graduate School, the Department of Environmental, Population and Organismic Biology, US Fish and Wildlife Service (Terry Ireland), and National Science Foundation Grant Nos. BSR9107827 to Richard G. Olmstead and DEB-9310802 to Richard G. Olmstead and Anna M. Goebel.

\section{References}

Akaike, H., 1974. A new look at the statistical model identification. IEEE Trans. Automat. Control 19, 716-723.

Altig, R., Dodd Jr., K., 1987. The status of the Armargosa toad (Bufo nelsoni) in the Amargosa River drainage of Nevada. Southwest. Nat. 32, 276-278.

Avise, J.C., Walker, D., Johns, G.C., 1998. Speciation durations and Pleistocene effects on vertebrate phylogeography. Proc. R. Soc. Lond. Ser. B Biol. Sci. 265, 17071712.

Arbogast, B.S., Edwards, S.V., Wakeley, J., Beerli, P., Slowinski, J.B., 2002. Estimating divergence times from molecular data on phylogenetic and population genetic timescales. Annu. Rev. Ecol. Syst. 33, 707-740.

Baxter, G.T., Stone, M.D., 1980. Amphibians and Reptiles of Wyoming, second ed. Wyoming Game and Fish Department.

Baird, S.F., Girard, C., 1852. Descriptions of new species of reptiles, collected by the US exploring expedition under the command of Capt. Charles Wilkes, USN. Proc. Acad. Nat. Sci. Phila. 6, 174.

Baird, S.F., Girard, C., 1853. List of reptiles collected in California by Dr. John L. Le Conte, with descriptions of new species. Proc. Acad. Nat. Sci. Phila. 6, 301.

Black, J.H., 1970. Unusual forms of Boreal toads Bufo boreas boreas (Amphibian: Bufonidae) in Glacier National Park. Proc. Okla. Acad. Sci. 50, 127-128.

Black, J.H., 1971. The toads genus Bufo in Montana. Northwest Sci. 45, 156-162.

Blair, A.P., 1955. Distribution, variation and hybridization in a relict toad (Bufo microscaphus) in Southwestern Utah. Am. Mus. Novit. 1722, 1-38.

Blair, W.F., 1963. Evolutionary relationships in North American toads of the genus Bufo: a progress report. Evolution 17, 1-16.

Blair, W.F., 1964. Evidence bearing on relationships of the Bufo boreas group of toads. Tex. J. Sci. XVI, 181-192.

Blair, F. W. 1972a.Evidence from hybridization. pp. 196-232 In, Frank. W. Blair, Evolution in the Genus Bufo, University of Texas Press, Austin, TX.

Blair, W.F., 1972b. Evolution in the Genus Bufo. University of Texas Press, Austin, TX

Blair, W.F., 1972c. Bufo of North and Central America. In: Blair, W.F. (Ed.), Evolution in the Genus Bufo. University of Texas Press, Austin TX, pp. 93-101.

Bogart, J.P., 1972. Karyotypes. In: Blair, W.F. (Ed.), Evolution in the Genus Bufo. University of Texas Press, Austin TX, pp. 171-195.

Bos, D.H., Sites Jr., J.W., 2001. Phylogeography and conservation genetics of the Columbia spotted frog (Rana luteiventris: amphibia, Ranidae). Mol. Ecol. 10, 1499-1513.

Brunsfield, S.J., Sullivan, J., Soltis, D.E., Soltis, P.S., 2001. Comparative phylogeography of northwestern North America: a synthesis. In: Silvertown, J., Antonovics, J. (Eds.), Integrating Ecology and Evolution in a Spatial Context. Blackwell Science Ltd., Oxford, pp. 319-339.

Burger, W.L., Bragg, A.N., 1946. Notes on Bufo boreas (B. and G.) from the Gothic region of Colorado. Proc. Okla. Acad. Sci. 27, 61-65.

Camp, C.L., 1916. Description of Bufo canorus, a new toad from the Yosemite National Park. Univ. Calif. Publ. Zool. 17, 59.

Camp, C.L., 1917a. Notes on the systematic status of the toads and frogs of California. Univ. Calif. Publ. Zool. 17, 115-125.

Camp, C.L., 1917b. An extinct toad from Rancho La Brea. Univ. Calif. Publ. Bull. Dept. Geol. 10, 287-292.

Castelloe, J., Templeton, A.R., 1994. Root probabilities for intraspecific gene trees under neutral coalescent theory. Mol. Phylogenet. Evol. 3, 102-113.

Carstens, B.C., Brunsfeld, S.J., Demboski, J.R., Good, J.D., Sullivan, J., 2005a. Investigating the evolutionary history of the Pacific Northwestern mesic forest ecosystem: hypothesis testing within a comparative phylogeographic framework. Evolution 59, 1639-1652.

Carstens, B.C., Degenhardt, J.D., Stevenson, A.L., Sullivan, J., 2005b. Accounting for coalescent stochasticity in testing phylogeographic hypotheses: modeling Pleistocene population structure in the Idaho giant salamander Dicamptodon aterrimus. Mol. Ecol. 14, 255-265.

Carstens, B.C., Knowles, L.L., 2007. Shifting distributions and speciation: species divergence during rapid climate change. Mol. Ecol. 16, 619-627.

Chaparro, J.C., Pramuk, J.B., Gluesenkamp, A.G., 2007. A new species of arboreal Rhinella (Anura: Bufonidae) from cloud forest of southeastern Peru. Herpetologica 63, 203-212.

Committee on the Status of Endangered Wildlife in Canada, 2002. COSEWIC Assessment and Status Report on the Western Toad, Bufo boreas, in Canada. COSEWIC, Ottawa. 
Conroy, C.J., Cook, J.A., 2000. Phylogeography of a post-glacial colonizer: Microtus Longicaudus (Rodentia: Muridae). Mol. Ecol. 9, 165-175.

Cope, E.D., 1875. Bufo pictus, Cope, sp.nov. P. 522 in report upon geographical and geological explorations and surveys west of the one-hundredth meridian. In Charge of First. Lieut. Geo. M. Wheeler, vol V. US Army, Engineer Dept. Washington, DC

Cope, E.D., 1889. Batrachia of North America. US Natl. Mus. Bull. 34, 1-525.

Corn, P.S., 2003. Endangered toads in the Rockies. In: Taylor, L., Martin, K., Hik, D., Ryall, A. (Eds.), Ecological and Earth Sciences in Mountain Areas. The Banff Centre, Banff, Alberta, pp. 43-51.

Darst, C.R., Cannatella, D.C., 2004. Novel relationships among hyloid frogs inferred from $12 \mathrm{~S}$ and 16S mitochondrial DNA sequences. Mol. Phylogenet. Evol. 31, 462-475.

Daugherty, C.H., Allendorf, F.W., Dunlap, W.W., Knudsen, K.L., 1983. Systematic implications of geographic patterns of genetic variation in the genus Dicamptondon. Copeia (3), 679-691.

Davidson, C., Fellers, G.M., 2005. Bufo canorus Camp 1916(a) Yosemite toad. In: Lannoo, M.J. (Ed.), Amphibian Declines: the Conservation Status of United States Species. University of California Press, Berkeley, California, pp. 400-401.

Environment Yukon, 2005. Yukon Amphibians. Government of Yukon.

Feder, J.H., 1973. Genetic Variation and Biochemical Systematics in Western Bufo. Master's Thesis. University of California, Berkeley, CA.

Feder, J.H., 1979. Natural hybridization and genetic divergence between the toads Bufo boreas and Bufo punctatus. Evolution 33, 1089-1097.

Fellers, G.M., 2005. Bufo exsul Myers, 1942(a) Black toad. In: Lannoo, M.J. (Ed.), Amphibian Declines: The Conservation Status of United States Species. University of California Press, Berkeley, California, pp. 406-408.

Felsenstein, J., 1985. Confidence limits on phylogenies: an approach using the bootstrap. Evolution 39, 783-791.

Felsenstein, J., 1992. Phylogenies from restriction sites: a maximum likelihood approach. Evolution 46, 159-173.

Frost, D.R., 2007. Amphibian Species of the World: an Online Reference Version 5.1 (10 October, 2007). American Museum of Natural History, New York, USA. Available from: <http://research.amnh.org/herpetology/amphibia/index.php>.

Frost, D.R., Grant, T., Faivovich, J., Bain, R.H., Haas, A., et al., 2006a. The amphibian tree of life. Bull. Am. Mus. Nat. Hist. 297, 370

Frost, C.R., Grant, T., Mendelson III, J.R., 2006b. Ollotis Cope, 1875 is the oldest name for the genus currently referred to as Cranopsis Cope, 1875 (Anura: Hyloides: Bufonidae). Copeia 2006, 558.

Fu, J., Weadick, C.J., Zeng, X., Wang, Y., Liu, Z., Zheng, Y., Li, C., Hu, Y., 2005. Phylogeographic analysis of the Bufo gargarizans species complex: a revisit. Mol. Phylogenet. Evol. 37, 202-213.

Goebel, A., 1996. Systematics and Conservation of Bufonids in North America and in the Bufo boreas Species Group. Ph.D. Dissertation. University of Colorado, Boulder, $\mathrm{CO}$

Goebel, A.M., 2005. Conservation systematics: the Bufo boreas species group. In: Lannoo, M.J. (Ed.), Amphibian Declines: The Conservation Status of United States Species. University of California Press, Berkeley, California, pp. 210-221.

Goebel, A.M., Donnelly, J., Atz, M., 1999. PCR primers and amplification methods for the $12 \mathrm{~S}$ ribosomal DNA, cytochrome oxidase I, cytochrome $b$, the control region in bufonids and other frogs and an overview of PCR primers available for analyses of amphibians. Mol. Phylogenet. Evol. 11, 163-199.

Goebel, A., Smith, H.M., Murphy, R.W., Morafka, D.J., 2005. Bufo nelsoni Stejneger, 1893 Amargosa toad. In: Lannoo, M.J. (Ed.), Amphibian Declines: The Conservation Status of United States Species. University of California Press, Berkeley, California, pp. 427-430.

Graybeal, A., 1993. The phylogenetic utility of cytochrome $b$ : lessons from Bufonid frogs. Mol. Phylogenet. Evol. 2 (3), 256-269.

Graybeal, A., 1997. Phylogenetic relationships of Bufonid frogs and tests of alternate macroevolutionary hypotheses characterizing their radiation. Zool. J. Linn. Soc. 119, 297-338.

Green, D.M., 1983. Allozyme variation through a clinal hybrid zone between the toads Bufo americanus and B. Hemiophrys in southeastern Manitoba. Herpetologica 39, 28-40.

Green, D.M., Gregory, P.T., 2007. Amphibians and Reptiles of British Columbia. University of British Columbia Press, Vancouver.

Green, D.M., Pustowka, C., 1997. Correlated morphological and allozyme variation in the hybridizing toads Bufo americanus and Bufo hemiophrys. Herpetologica 53, $218-228$.

Green, D.M., Sharbel, T.F., Kearsley, J., Kaiser, H., 1996. Postglacial range fluctuation, genetic subdivision and speciation in the western North American spotted frog complex, Rana pretiosa. Evolution 50, 374-390.

Grismer, L.L., 2002. Amphibians and Reptiles of Baja California, Its Pacific Islands and the Islands in the Sea of Cortes. University of California Press, Berkeley.

Hammerson, G.A., 1999. Amphibians and Reptiles in Colorado, second ed. University Press of Colorado and Colorado Division of Wildlife, Niwot, CO.

Herbert, P.D.N., Cywinska, A., Ball, S.L., deWaard, J.R., 2003. Biological identification through DNA barcodes. Proc. R. Soc. Lond. B Biol. 270, 313-321.

Herbert, P., Gregorory, T., 2005. The promise of DNA barcoding for taxonomy. Syst. Biol. 5, 852-859.

Hewitt, G., 2000. The genetic legacy of the quaternary ice ages. Nature 405, 907913.

Hewitt, G.M., 1996. Some genetic consequences of ice ages, and their role in divergence and speciation. Biol. J. Linn. Soc. 58, 247-276.

Highton, R., Webster, T.P., 1976. Geographic protein variation and divergence in populations of the salamander Plethodon cinereus. Evolution 30, 33-45.
Hillis, D.M., 1988. Systematics of the Rana pipiens complex: puzzle and paradigm. Annu. Rev. Ecol. Syst. 19, 39-63.

Hovingh, P., 1997. Amphibians in the eastern Great Basin (Nevada and Utah, USA): a geographical study with paleozoological models and conservation implications. Herpetol. Nat. Hist. 5, 97-134.

Howard, J.H., Seeb, L.W., Wallace, R., 1993. Genetic variation and population divergence in the Plethodon vandykei species group (Caudata: Plethodontidae). Herpetologica 49, 238-247.

Hubbs, C.L., Miller, R.R., 1948. The Great Basin. The zoological evidence. Bull. Univ. Utah 20, 18-166.

Huelsenbeck, J.P., Bollback, J., Levine, A.M., 2002. Inferring the root of a phylogenetic tree. Syst. Biol. 5, 32-43.

Huelsenbeck, J.P., Ronquist, F., 2005. MRBAYES: Bayesian inference of phylogenetic trees. Bioinformatics 17, 754-755

Jaeger, J.R., Riddle, B.R., Bradford, D.F., 2005. Cryptic Neogene vicariance and quaternary dispersal of the red-spotted toad (Bufo punctatus): insights on the evolution of North American warm desert biotas. Mol. Ecol. 14, 30333048 .

Karlstrom, E.L., 1958. Sympatry of the Yosemite and Western toads in California. Copeia 2, 152-153.

Karlstrom, E.L., 1962. The toad genus Bufo in the Sierra Nevada of California Ecological and Systematic Relationships, vol. 62. University of California Press, Publ. Zool., pp. 1-104.

Kocher, T.D., Thomas, W.K., Meyer, A., Edwards, S.V., Paabo, S., Villablanca, F.X. Wilson, A.C., 1989. Dynamics of mitochondrial DNA evolution in animals: amplification and sequencing with conserved primers. Proc. Natl. Acad. Sci. USA 86, 6196-6200.

Koetsier, P.A., Schorr, J., Doerfler, W., 1993. A rapid optimized protocol for downward alkaline southern blotting of DNA. BioTechniques 15, 260-262.

Kuchta, S.R., Tan, A.M., 2005. Isolation by distance and post-glacial range expansion in the rough skinned newt, Taricha granilosa. Mol. Ecol. 14, 225-244.

Lamb, T., Avise, J.C., 1987. Morphological variability in genetically defined categories of anuran hybrids. Evolution 41, 157-165.

Laurenti, J.N., 1768. Specimen medicum, exhibens synopsin reptilium emendatum cum experimentis circa venena ET antidota Reptilium Austriacorum. Wien.

Lee-Yaw, J.A., Irwin, J.T., Green, D.M., 2008. Postglacial range expansion from northern refugia by the wood frog Rana sylvatica. Mo. Ecol. 17, 867-884.

Lemmon, A.R., Moriarty, E.C., 2004. The importance of proper model assumption in Bayesian phylogenetics. Syst. Biol. 53, 265-277.

Linsdale, J.M., 1940. Amphibians and reptiles in Nevada. Proc. Am. Acad. Arts Sci. 73 197-257.

Liu, W., Lathrop, A., Fu, J., Yang, D., Murphy, R.W., 2000. Phylogeny of east Asian Bufonids inferred from mitochondrial DNA sequences (Anura: Amphibia). Mol. Phylogenet. Evol. 14, 423-435.

Macey, J.R., Shulte II, J.A., Larson, A., Fang, Z., Wang, Y., Tuniyev, B.S., Papenfuss, T.J., 1998. Phylogenetic relationships of toads in the Bufo bufo species group from the eastern escarpment of the Tibetan Plateau: a case of vicariance and dispersal. Mol. Phylogenet. Evol. 9, 80-87.

Macey, J.R., Strasburg, J.L., Brisson, J.A., Vredenburg, V.T., Jennings, M., Larson, A., 2001. Molecular phylogenetics of western North American frogs of the Rana boylii species group. Mol. Phylogenet. Evol. 19, 131-143.

Maniatis, T., Fritsch, E.F., Sambrook, J., 1982. Molecular Cloning: A Laboratory Manual. Cold Spring Harbor Publications, Cold Spring Harbor.

Masta, S.E., Laurent, N.M., Routman, J., 2003. Population genetic structure of the toad Bufo woodhousii: an empirical assessment of the effects of haplotype extinction on nested cladistic analysis. Mol. Ecol. 12, 1541-1554.

Masta, S.E., Sullivan, B.K., Lamb, T., Routman, E.J., 2002. Molecular systematic, hybridization, and phylogeography of the Bufo americanus complex in eastern North America. Mol. Phylogenet. Evol. 24, 302-314

Maxson, L.R., Song, A.R., Lopata, R., 1981. Phylogenetic relationships among North American toads, genus Bufo. Biochem. Syst. Ecol. 9, 347-350.

McCusker, M.S., Parkinson, E., Taylor, E.B., 2000. Mitochondrial DNA variation in rainbow trout (Oncorhynchus mykiss) across its natives range: testing biogeographical hypotheses and their relevance to conservation. Mol. Ecol. 9, 2089-2108.

Mead, L.S., Clayton, D.R., Nauman, R.S., Olsen, D.H., Pfrender, M.E., 2005. Newly discovered populations of salamanders from Siskiyou County, California, represent a species distinct form Plethodon stormi. Herpetologica 61, 158177.

Mebert, K., 2008. Good species despite massive hybridization: genetic research on the contact zone between the water snakes Nerodia sipedon and $N$. fasciata in the Carolinas, USA. Mol. Ecol. 17, 1918-1929.

Meier, R., Shiyang, K., Vaidya, G., NG, P.K.L., 2006. DNA barcoding and taxonomy in Diptera: a tale of high intraspecific variability and low identification success Syst. Biol. 55 (5), 715-728.

Mifflin, M.D., Wheat, M.M., 1979. Pluvial Lakes and Estimated Pluvial Climates of Nevada. Nevada Bureau of Mines and Geology Bull. No. 94. Mackay School of Mines, U. Nevada, Reno.

Miller, M.P., Haig, S.M., Wagner, R.S., 2005. Conflicting patterns of genetic structure produced by nuclear and mitochondrial markers in the Oregon salamanders (Batrachoseps wrighti): implications for conservation efforts and species management. Conserv. Genet. 6, 275-287.

Moritz, C., Schneider, C.J., Wake, D.B., 1992. Evolutionary relationships within the Ensatina eschscholtzii complex confirm the ring species interpretation. Syst. Biol. 41, 273-291. 
Morton, M.L., Sokoloski, K.N., 1978. Sympatry in Bufo boreas and Bufo canorus an additional evidence of natural hybridization. Bull. South. CA Acad. Sci. 77, 5255.

Mullally, D.P., Powell, D.H., 1958. The Yosemite toad: northern range extension and possible hybridization with the Western toad. Herpetologica 14, 31-33.

Muths, E., Nanjappa, P., 2005. Bufo boreas Baird and Girard 1852b western toad. In: Lannoo, M.J. (Ed.), Amphibian Declines: The Conservation Status of United States species. University of California Press, Berkeley, California, pp. 392-396.

Myers, G.S., 1942. The Black Toad of Deep Springs Valley, Inyo County, California. Occas. Pap. Mus. Zool., University of Michigan 460, pp. 3-13 and Plates I-III.

Nielson, M.K., Lohman, L.K., Daugherty, C.H., Allendorf, F.W., Knudsen, K.L., Sullivan, J., 2006. Allozyme and mitochondrial DNA variation in the tailed frog (Anura: Ascaphus): the influence of geography and gene flow. Herpetologica 62, 235258.

Nielson, M.K., Lohman, L.K., Sullivan, J., 2001. Phylogeography of the tailed frog (Ascaphus truei): implications for the biogeography of the Pacific Northwest. Evolution 55, 157-160.

Nussbaum, R.A., Brodie Jr., E.D., Storm, R.M., 1983. Amphibians and Reptiles of the Pacific Northwest. University Press of Idaho, Moscow, ID. $332 \mathrm{pp}$

Nosil, P., 2008. Speciation with gene flow could be common. Mol. Ecol. 17, 2103 2106

Nylander, J.A.A., 2004. MrModeltest v2. Program distributed by the author. Evolutionary Biology Center, Uppsala University.

Ogden, T.H., Rosenberg, M.S., 2007. How should gaps be treated in parsimony? A comparison of approaches using simulation. Mol. Phylogenet. Evol. 42, 817826.

Palumbi, S.R., Martin, A., Romano, S., McMillan, W.O., Stice, L., Grabowski, G., 1991. The Simple Fool's Guide to PCR, Version 2.0. Privately Published Document Compiled by S. Palumbi, Dept. Zoology, Univ. Hawaii, Honolulu, HI, 96822.

Pauly, G.B., Hillis, D.M., Cannatella, D.C., 2004. The history of a Nearctic colonization: molecular phylogenetic and biogeography of the Nearctic toads (Bufo). Evolution 58, 2517-2535.

Pielou, E.C., 1991. After the Ice Age: the Return of Life to Glaciated North America. University of Chicago Press.

Posada, D., Crandall, K.K., 1998. Modeltest: testing the model of DNA substitution. Bioinformatics 14 (9), 817-818.

Pramuk, J.B., 2006. Phylogeny of South America Bufo (Anura: Bufonidae) inferred from combined evidence. Zool. J. Linn. Soc. 146, 407-452.

Pramuk, J.B., Hass, C.A., Hedges, S.B., 2001. Molecular phylogeny and biogeography of West Indian toads (Anura: Bufonidae). Mol. Phylogenet. Evol. 20, 294-301.

Rambaut, A., 2008. FigTree 1.1.2. Institute of Evolutionary Biology, Edinburg, UK Available from: <http://tree.bio.ed.ac.uk/software/>.

Rambaut, A., Drummond, A.J., 2007. Tracer 1.4. Institute of Evolutionary Biology, Edinburg, UK. Available from: <http://tree.bio.ed.ac.uk/software>.

Rodriquez-Robles, J.A., Denardo, D.E., Staubs, R.E., 1999. Phylogeography of the California mountain kingsnake, Lampropeltis zonata (Colubridae). Mol. Ecol. 8 1923-1934.

Ronquist, F., Huelsenbeck, J.P., 2003. MRBAYES 3: Bayesian phylogenetic inference under mixed models. Bioinformatics 19, 1572-1574.

Ross, D.A., Esque, T.C., Fridell, R.A., Hovingh, P., 1995. Historical distribution, current status, and a range extension of Bufo boreas in Utah. Herpetol. Rev. 26, 187-189.

Sanders, O., Cross, J.C., 1963. Relationships between certain North American toads as shown by cytological study. Herpetologica 19, 248-255.

Schmidt, K.P., 1953. A checklist of North American Amphibians and Reptiles, sixth ed. American Society of Ichthyologists and Herpetologists, University of Chicago Press, Chicago, IL.

Schuierer, F.W., 1963. Notes on two populations of Bufo exsul Myers and commentary on speciation within the Bufo boreas group. Herpetologica 18, 262-267.

Schueler, F.W., 1982. Sexual colour differences in Canadian Western Toads, Bufo boreas. Can. Field Nat. 96, 329-332.

Schwarz, G., 1978. Estimating the dimension of a model. Ann. Stat. 6, 461-464.

Shaffer, H.B., Fellers, G.M., Magee, A., Voss, S.R., 2000. The genetics of amphibian declines: population substructure and molecular differentiation in the Yosemite toad, Bufo canorus (Anura, Bufonidae) based on single-stranded conformation polymorphism analysis (SSCP) and mitochondrial DNA sequence data. Mol. Ecol. 9, 245-257.

Shaffer, H.B., McKnight, M.L., 1996. The polytypic species revisited: genetic differentiation and molecular phylogenetics of the tiger salamander Ambystoma tigrinum (Amphibia:Caudata) complex. Evolution 50, 417-433.

Shaffer, B.H., Fellers, G.M., Randal, V.S., Oliver, J.C., Pauly, G.B., 2004. Species boundaries, phylogeography and conservation genetics of the red-legged frog (Rana auroraldraytonii) complex. Mol. Ecol. 13, 2667-2677.
Simandle, E.T., 2006. Population Structure and Conservation of Two Rare Toad Species (Bufo exsul and Bufo nelsoni) in the Great Basin, USA. Ph.D. Dissertation. University of Nevada, Reno.

Simandle, E.T., Peacock, M.M., Zirelli, L., Tracey, C.R., 2006. Sixteen microsatellite loci for the Bufo boreas group. Mol. Ecol. Notes 6, 116-119.

Smith, M.A., Green, D.M., 2004. Phylogeography of Bufo fowleri at its northern range limit. Mol. Ecol. 13, 3723-3733.

Soltis, D.E., Gitzendanner, M.A., Strenge, D.D., Soltis, P.S., 1997. Chloroplast DNA intraspecific phylogeography of plants from the Pacific Northwest of North America. Plant Syst. Evol. 206, 353-373.

Southern, E.M., 1975. Detection of specific sequences among DNA fragments separated by gel electrophoresis. J. Mol. Biol. 98, 503-517.

Stebbins, R.C., 1951. Amphibians of Western North America. University of California Press, Berkeley, CA. pp. 1-539.

Stebbins, R.C., 2003. A Field Guide to Western Reptiles and Amphibians, third ed. Houghton Mifflin Company, Boston.

Steele, C.A., Storfer, A., 2006. Coalescent-based hypothesis testing supports multiple Pleistocene refugia in the Pacific Northwest for the Pacific giant salamander (Dicamptodon tenebrosus). Mol. Ecol. 15, 2477-2487.

Stejneger, L., 1893. Annotated list of the reptiles and Batrachians collected by the Death Valley expedition in 1891 with descriptions of new species. N. Am. Fauna 7, 220.

Stephens, M.R., 2001. Phylogeography of the Bufo boreas (Anura, Bufonoidea) Species Complex and the Biogeography of California. MA Thesis. Sonoma State University, CA.

Stöck, M., Mortiz, G., Hickerson, M., Frynta, D., Dujsebayeva, T., Eremchenko, V., Macey, R.J., Papenfuss, T.J., Wake, D.B., 2006. Evolution of mitochondrial relationships and biogeography of Palearctic Green toads (Bufo viridis subgroup) with insights in their genomic plasticity. Mol. Phylogenet. Evol. 41, 663-689.

Stokes, W.L., 1986. Geology of Utah. Utah Geol Min Sur. and the Utah Mus. Nat. Hist. UMNH Publ. \# 6.

Storer, T.I., 1925. A synopsis of the Amphibia of California. Univ. CA Publ. Zool 27, 1342

Swofford, D.L., 2002. PAUP*: Phylogenetic Analysis Using Parsimony (*and Other Methods), Version 4.0b10. Sinauer Associates, Sunderland, MA.

Tan, A.M., Wake, D.B., 1995. MtDNA phylogeography of the California newt, Tarich torosa (Caudate, Salamandridae). Mol. Phylogenet. Evol. 4, 383-394.

Thompson, L., 2005. Endangered and threatened wildlife and plants; revised 12month finding for the southern Rocky Mountain distinct population segment of the boreal toad (Bufo boreas boreas). Fed. Regist. 70, 56880-56884.

Thompson, P.D., Fridell, R.A., Wheeler, K.K., Bailey, C.L., 2004. Distribution of Bufo boreas in Utah. Herpetol. Rev. 35, 255-257.

Tihen, J.A., 1962. Osteological observations of New World Bufo. Am. Midland Nat. 67, 157-183.

Tschudi, J.J.V., 1845. Reptilium conspectus quae in republica peruana reperiuntur ET pleraquae observata vel collecta sunt in itinere a Dr. J. J. de Tschudi. Arch. Für Naturgeschichte $11,150-170$

US Fish and Wildlife Service, 2002. Endangered and threatened wildlife and plants; 12-month finding for a petition to list the Yosemite toad. Fed. Regist. 67, $75834-75843$.

Vredenburg, V.T., Bingham, R., Knapp, R., Morgan, J.A.T., Moritz, C., Wake, D., 2007. Concordant molecular and phenotypic data delineate new taxonomy and conservation priorities for the endangered mountain yellow-legged frog. Zool. J. Linn. Soc. 271, 361-374.

Wagner, R.S., Miller, M.P., Crisafulli, C.M., Haig, S.M., 2005. Geographic variations, genetic structure, and conservation unit designation in the Larch Mountains salamander (Plethodon larselli). Can. J. Zool. 83, 396-406.

Wake, D., 1997. Incipient species formation in salamanders of the Ensatina complex. Proc. Natl. Acad. Sci. USA 94, 7761-7767.

Waldman, B., Rice, J.E., Honeycutt, R.L., 1992. Kin recognition and incest avoidance in toads. Am. Zool. 32, 18-30.

Wheeler, W.C., 1990. Nucleic acid sequence phylogeny and random outgroups. Cladistics 6, 363-368.

Wilke, T., Duncan, N., 2004. Phylogeographical patterns in the American Pacific Northwest: lesson from the Arionid slug Prophysaon coeruleum. Mol. Ecol. 13, 2303-2315.

Wood, D.A., Fisher, R.N., Reeder, T.W., 2008. Novel patterns of historical isolaton, dispersal, and secondary contact across Baja California in the Rosy Boa (Lichanura trivigata). Mol. Phylogenet. Evol. 46, 484-502.

Wright, A.H., Wright, A.A., 1949. Handbook of Frogs and Toads of the United States and Canada. Comstock Publishing Company, Inc., Ithaca, New York

Zink, R.M., 1996. Comparative phylogeography in North American birds. Evolution $50,308-317$. 